\title{
Los Fueros medievales dentro de la producción de Alfonso García-Gallo
}

\author{
The Medieval Charters \\ within Alfonso García-Gallo's Production
}

\author{
Pedro Andrés PORRAS ARBOLEDAS \\ Catedrático acreditado de Historia del Derecho \\ Departamento de Historia del Derecho \\ Instituto de Metodología e Historia de la Ciencia Jurídica \\ Facultad de Derecho. Universidad Complutense de Madrid \\ pporras@der.ucm.es
}

Recibido: 21 de febrero de 2011

Aceptado: 1 de abril de 2011

\section{RESUMEN}

En este estudio se pasa revista al programa diseñado por García-Gallo para el estudio de los fueros medievales hispánicos, mediante el método histórico-crítico, así como a sus realizaciones, tanto por el propio García-Gallo como por sus discípulos, entre los cuales sólo puede afirmarse que haya sido fiel a los postulados del maestro Ana Barrero.

PALABRAS CLAVE: García-Gallo, fueros medievales, método histórico-crítico.

\begin{abstract}
This paper reviews the syllabus designed by the Professor García-Gallo for the study of the Hispanic medieval charters, using the historical-critical method. Also reviewed are the syllabus implementations, from the own García-Gallo as well as from his disciples, among which only Ana Barrero can be said to have been faithful to the master's tenets.
\end{abstract}

KEYWORDS: Alfonso García-Gallo, Medieval Charters, historical-critical method.

\section{RÉSUMÉ}

Cette étude analyse le programme conçu par le professeur García-Gallo pour l'étude des fors médiévales hispaniques, à l'aide de la méthode historico-critique, aussi bien quant aux réalisations du dit programme, faites par García-Gallo lui-même aussi que par ses disciples, parmi lesquels seulement Ana Barrero peut se reconnaître fidèle aux préceptes du maître.

MOTS CLÉ : García-Gallo, fors médiévaux, la méthode historico-critique.

\section{ZUSAMMENFASSUNG}

Dieser Aufsatz lässt unter Zuhilfenahme der historisch-kritischen Methode das von García-Gallo entworfene Programm für die Untersuchung der mittelalterlichen «fueros» Spaniens Revue passieren. Dabei 
werden nicht nur die Werke von García-Gallo, sondern auch die seiner Schüler herangezogen, wobei klar die Treue zum wissenschaftlichen Vorbild Ana Barrero aufscheint.

SCHLÜSSELWÖRTER: García-Gallo, mittelalterliche «fueros», historisch-kritische Methode.

SUMARIO: 1. La obra de Alfonso García-Gallo. 2. La obra de sus discípulos. 2.1. José Martínez Gijón y sus propios discípulos. 2.2. Gonzalo Martínez Díez. 2.3. Mari Luz Alonso Martín. 2.4. Ana María Barrero García. 2.4.1. Trabajos sobre fueros castellanos y aragoneses. 2.4.2. Trabajos sobre Costums catalanas y valencianas. 2.4.3. Trabajos conclusivos. 3. Conclusiones.

\section{La obra de Alfonso García-Gallo}

No cabe duda de que uno de los temas señeros de investigación que ocuparon la atención de la extensa actividad del profesor García-Gallo fue el de los fueros medievales; en ello no hacía sino seguir la senda marcada durante los años de su formación intelectual por sus maestros del Centro de Estudios Históricos, que lamentaban el escaso y sesgado conocimiento que se tenía, antes de nuestra última contienda civil, de los textos forales de todos los territorios españoles. Allí, en dicho Centro, GarcíaGallo pudo entrar en contacto con el fichero de fueros elaborado a la sazón para completar tanto la Colección como el Catálogo de fueros, elaborados en su día por Muñoz y Romero, cuyo meritorio esfuerzo distaba mucho de recoger toda la copiosa documentación existente. ${ }^{1}$

De acuerdo con la obra publicada, la primera referencia con que contamos para saber el punto de que partía el autor a la hora de enfrentarse con los fueros medievales, es el Manual que, junto a Román Riaza, editó en 1934, cuando apenas contaba con 23 años de edad. Este sería el esquema de su nivel de conocimientos y de cómo los categorizaba: ${ }^{2}$

$\left.1^{\circ}\right)$ Alta Edad Media:

Fueros Locales

- cartas-pueblas (o de población, especie de contratos agrarios colectivos)

- fueros breves, concedidos por el rey o señores con inmunidad, con un cierto carácter contractual

- modos de crearse: ex novo, por extensión de otro anterior, con carácter supletorio, a elegir entre varios, adiciones sobre el original, confirmaciones.

— no incluyen un ordenamiento completo, sino unas normas privilegiadas

— tendencia a la unificación del Derecho

\footnotetext{
${ }^{1}$ Probablemente el hecho de que García-Gallo nunca ingresase en la Real Academia de la Historia explique el que ni él ni sus discípulos cayeran en la cuenta de la existencia, dentro de los fondos de su biblioteca, de lo que se puede considerar como los materiales preparatorios recogidos por Muñoz y Romero para la continuación de su Colección de fueros (manuscrito 9/6.448).

${ }^{2}$ Román Riaza y Alfonso García-Gallo, Manual de Historia del Derecho Español, Madrid, 1934, pp. $223-240$ y $340-368$.
} 
— ejemplos de fueros interesantes...

Fueros Territoriales

- Fuero de León de 1020

- Concilio de Coyanza de 1050

- Capitulares carolingias

- Usatges

Fórmulas y diplomas

— formularios notariales

— fórmulas de diplomas: protocolo (invocación, suscripción, salutación), texto (preámbulo, notificación, promulgación, narratio, dispositio), cláusulas finales (escatocolo, con datas, firmas y sellos).

- transmisión: originales y copias (cartularios, becerros, tumbos)

— Edad Diplomática (a falta de otras fuentes)

$\left.2^{\circ}\right)$ Baja Edad Media:

Fueros Locales

- fueros extensos

- extensión del Fuero de Cuenca

- otros que no forman familia

- fuentes catalanas (consuetudines / costums)

— ordenanzas u ordinacions (Recognoverunt, O. de Sanctacilia)

Fueros Territoriales

- la obra alfonsina

— colecciones de fallos judiciales (LFC, FVC, Devysas, Pseudo Ordenamientos)

- leyes de moros, en romance / de judíos

- Cataluña: presencia del Derecho Común

- Mallorca

- Aragón: Código de Huesca (de Vidal de Cañellas)

- Navarra / - Valencia / - Vascongadas

- Derecho Marítimo (Rôles d'Oléron, Libro del Consulado del Mar)

Fórmulas y documentos

— fórmulas: de cancillería o de notarios públicos

Como se ve, se trataba de un esquema tradicional, tanto en lo relativo a los cortes cronológicos como a la división tripartita fueros locales/fueros territoriales/fórmulas, y dentro de la categoría de los fueros locales: cartas-pueblas /fueros breves /fueros extensos (dentro de éstos últimos, a su vez, el problema de la existencia o no de familias).

En ese mismo año, GG publicó su primer trabajo de investigación sobre fueros, o, más bien, sobre unas fazañas del siglo XII, recogido en el Anuario, revista de la que ya no se separaría el resto de su vida académica, en especial, tras la guerra civil. ${ }^{3}$

${ }^{3}$ «Una colección de fazañas castellanas del siglo XII», AHDE, XI, 1934, pp. 522-532. Comentario y edición de una pequeña colección de fazañas conservadas en el manuscrito 697 de la Biblioteca Nacional de Madrid. Incluyen una serie de casos acaecidos en Palenzuela (Palencia) y sus alrededores, sin que vengan fechados, si bien hay posibles menciones a Alfonso VI y con seguridad a Alfonso el Emperador. De ser cierta la atribución al conquistador de Toledo, habría que fechar estar fazañas entre 1104 y 1109; 
En este trabajo ya se aprecia el interés del autor por utilizar el método históricocrítico, como siempre y en lo sucesivo, sobre documentos ya editados, dado que la investigación de archivo nunca estuvo entre sus prioridades. ${ }^{4}$

Habrá que esperar a la segunda mitad de la década de los años 50 para que GG se vuelva a interesar por el asunto, o, al menos, para que edite los resultados de sus trabajos; de hecho, a la vista de su siguiente artículo, más parece que el autor estuvo realizando labor de campo y planteándose cómo establecer un programa de actuación. Esto es que lo que puede inferirse del contenido de su trabajo «Aportación al estudio de los fueros», donde propone las líneas de investigación y el método que, a su juicio, debían seguirse en años sucesivos a fin de esclarecer el aparentemente simple mundo interno de los fueros. ${ }^{5}$

de atribuirse a Alfonso VII, procederían de un momento situado entre su ascenso al trono, en 1126, hasta 1135, en que asume la condición de Imperator. GG parece decantarse por esta segunda opción. Sólo se atreve a datar con cierta seguridad la fazaña $8^{\mathrm{a}}$, entre 1135 y 1157, por venir atribuida al Emperador.

Se halla redactada en romance bárbaro por algún práctico local, siendo menos antigua y extensa que la colección inserta en el fuero de Castrojeriz, si bien su contenido es más variado, según quiere GG. Cuatro de esas fazañas son dadas por el rey $(1,4,5$ y 8$)$, en tanto que el merino de la villa lo hace en dos ocasiones ( 2 y 3$)$, todas ellas en aplicación del fuero municipal.

Versaban sobre la pena de los ladrones sorprendidos in fraganti (1 y 4), el castigo del homicidio (3 y 7), violencias y deshonras cometidas en palacios y villas ( 5 y 8 ) y el homicidio casual (2 y 6). Se trata de pruebas de la aplicación de un fuero preexistente, al que vienen a confirmar. Así, la fazaña hay que interpretarla tanto como decisión judicial, como aplicación de la norma jurídica, por la vía judicial o no.

${ }^{4}$ No deja de ser curiosa para mí esta actitud de GG, que recuerda aquella manida frase de Unamuno, ¡Qué inventen ellos!, esto es, ;Que publiquen ellos!; desde luego, no es una postura extraña en aquellos años, pues fue compartida por muchos otros estudiosos de la Historia del Derecho, como si la investigación de archivo fuese una labor subalterna o de sujetos sin grandes «iluminaciones».

${ }^{5}$ «Aportación al estudio de los Fueros», AHDE, XXVI, 1956, pp. 387-446. Tiene dos partes: en la primera se cuestiona el concepto «Fuero», su origen y sus contenidos; respecto a los orígenes del concepto, entiende que procede del término latino Forum, pero en el sentido de «modo de actuar el tribunal, tramitación en él», de acuerdo con una constitución del 398; con posterioridad, los hombres altomedievales equipararían la costumbre, como forma de creación de derecho, que quedaría a la apreciación del tribunal, con el término «Fuero». Así, Forum pasaría a equivaler a fazaña, iudicium o, simplemente, norma jurídica.

A partir de ahí, fuero se generaliza para significar Derecho, carta o libro de Derecho, ordenamiento jurídico no formulado o ley. Sin embargo, es la recepción del Derecho Común la que acabaría arrinconando el viejo término, al reservarse para designar el Derecho tradicional, por oposición al ahora nuevamente recibido, el privilegio o un Derecho especial. A continuación se centra en el mundo de los derechos locales, donde los fueros alcanzaron su plenitud histórica, para tratar de establecer una clasificación de estos textos; para ello, distingue entre los fueros de carácter agrario, los concedidos por los príncipes como privilegios y las redacciones de origen consuetudinario. Completa este estudio con el repaso a la geografía de los fueros, distinguiendo las áreas aragonesa-navarra y riojana-burgalesa, la celtibérica, la vetona, la catalana y otras.

Concluye con la necesidad de proceder al estudio sistemático de los fueros, a fin de acabar con la inconsistencia de muchos de los estudios sobre el derecho medieval existentes en aquellos momentos. Para ello fija los siguientes objetivos: investigar origen, autor, elementos integrantes y fases de redacción; establecer una clasificación de los mismos; buscar las conexiones entre textos, a la búsqueda de las familias de fueros. Muestra una fina intuición cuando adelanta que la división entre Derecho local/De- 
De este artículo decía Gonzalo Martínez Díez, ${ }^{6}$ «El año 1956 publicaba el profesor García-Gallo en el Anuario de Historia del Derecho un orientador artículo que él titulaba Aportación al estudio de los fueros y en el que recogía en una panorámica de conjunto todas sus múltiples observaciones, experiencias y conclusiones de muchos años dedicados al estudio del derecho medieval castellano; su trabajo era el fruto de la madurez». ${ }^{7}$

Para entender mejor esa travesía del desierto de GG debemos fijarnos en el que sería su Manual definitivo, cuya primera edición debe de fecharse en los años 19591962. Del mismo interesan para nuestro intento dos apartados: en primer lugar, el llamado por el autor «sistema de fuentes de la Alta Edad Media», donde es posible apreciar la evolución sufrida desde 1934 en cuanto a la categorización de las fuentes; ${ }^{8}$ por otro lado, resulta significativo que como introducción al segundo tomo, donde se recogían los textos a comentar, incluyera un extenso apartado, dedicado a la metodología histórico-jurídica, que más parece pensado para futuros doctorandos que para estudiantes de primer año de licenciatura. ${ }^{9}$

recho territorial debería ser revisada, tal y como haría años después el profesor Iglesia, no así cuando establece una distinción entre el derecho creado en los círculos rurales y el de las urbes. Se trata de un artículo programático, que habría las líneas de investigación, que luego serían seguidas, en parte, por él mismo y, sobre todo, por algunos de sus discípulos.

${ }^{6}$ «El fuero de Soria: génesis y fuentes», AHDE, LXXVI, 2006, p. 21.

${ }^{7}$ Por esas fechas, GG se ocupó de extender en suelo francés algunas de sus ideas sobre el fin del mundo foral («La crise des Droits locaux et leur survivance à l'époque moderne», Annales de la Faculté de Droit de Toulouse, VI, 1958, pp. 287-301; publicado en castellano como «Crisis de los derechos locales y su vigencia en la Edad Moderna», Cuadernos de Derecho Francés, X-XI, 1955, pp. 69-81, y IV Jornadas franco-españolas de Derecho comparado, Barcelona, 1958, pp. 69-81).

${ }^{8}$ Sistema de fuentes de la AEM. 1. Fuentes del Derecho secular:

- caracteres generales: originalidad del nuevo sistema; sus límites cronológicos (siglos VIII-XIII, para Castilla)

- fuentes en general, clases: costumbre, decisiones judiciales (fazañas), disposiciones legales (fueros municipales: caracteres - otorgar normas privilegiadas, fijar derecho preexistente, corto número de disposiciones-; concesión: por el rey, el señor o el concejo, generalmente pactado con sus beneficiarios; circunstancias: al conquistarse, para introducir novedades, para pacificar desavenencias con señores), leyes generales (Fuero de León o Constituciones catalanas de paz y tregua), pactos privados. Redacciones y refundiciones de Derecho Local (tipos y difusión, elementos integrantes, origen).

- distintos sistemas de fuentes: visigótico o mozárabe: origen (Liber), Cataluña siglos VIII-X (capitulares, Usatges, costumbres y privilegios locales), León (reinstauración del Liber), Toledo, difusión del Liber como fuero local; de derecho libre o de albedrío: caracteres, redacciones de derecho castellano (Pseudo ordenamientos, LFC, FVC); de fueros breves: observaciones generales; fueros principales: castellanos, leoneses, pirenaicos, navarros, Extremadura castellano-aragonesa, Zaragoza; y de fueros extensos: difusión y época; fueros principales: áreas aragonesa y navarra, de la Extremadura castellana, de la Extremadura leonesa. Su aplicación («encierran todas las normas del Derecho local») (Manual de Historia del Derecho Español, Madrid, 1967, $3^{\text {a }}$ edición, I, pp. 361-379).

${ }^{9}$ Metodología histórico-jurídica:

- fuentes de conocimiento. Fuentes escritas: conservación de textos (en archivos, bibliotecas, particulares); lectura de textos; lengua de las fuentes; transmisión de textos y valor de las fuentes (autenticidad). Fuentes no escritas (arqueología, costumbre). 
En cualquier caso, no puede decirse de GG que no predicara con el ejemplo: de hecho, ya en 1961, aprovechando las ventajas que le ofrecía el ser el director del Anuario, empezó a publicar lo mejor de su producción en lo referente al tema de que nos venimos ocupando. En ese año se fijó en los fueros de Medinaceli, si bien las fuentes conservadas no favorecían un estudio muy lucido para el autor, que despachó el tema en apenas dieciocho páginas; no obstante lo cual, en este trabajo ya apunta lo que sería su método: el estudio diplomático e histórico de las fuentes, en un intento por reconstruir la historia interna del fuero. ${ }^{10}$

Sin embargo, los mejores trabajos de fueros de GG hay que situarlos en los años 1969-1975, realizados en su etapa de plena madurez. En ese septenato se ocupó de los fueros de León, Llanes, Benavente y Toledo, trabajos, sin duda, importantes, pero que parecen poca cosa si se tiene en cuenta la gran capacidad de trabajo de este autor.

En lo referente al Fuero de León, GG estructura el trabajo en torno a siete apartados: ${ }^{11}$

$1^{\circ}$ ) Prehistoria del texto (primeras noticias, edición y descubrimiento de un nuevo texto en Braga).

$2^{\circ}$ ) Textos conservados (redacciones ovetense - un siglo posterior al original- y portuguesa —del siglo XIII—; relaciones entre ambas; confirmación del Fuero por doña Urraca en 1109; las referencias más antiguas al Fuero, desde 1032, poco concluyentes).

$3^{\circ}$ ) La Familia del Fuero (difusión del Fuero: concesiones del Fuero a Villavicencio, Pajares, Castrocalbón y Benavente; fueros basados en el de León, sin citarlo: Rabanal, Villafranca del Bierzo y Puebla de Sanabria; otros tardíos (siglo XIII): Milmanda, Parga, Llanes y Villavicencio, 1221).

$4^{\circ}$ ) La crítica textual (cotejo, tabla de concordancias (variedad de extensión y contenidos), extensión distintas de los textos, cuestiones reguladas, las distintas redacciones, el texto ovetense no reproduce el auténtico Fuero; resultados de la crítica textual: el Fuero evolucionó a lo largo de los siglos XI y XII; núcleo central, el de los preceptos que se encuentran en todos los textos, recogido en Apéndice II).

— método de investigación: fase inicial de la investigación (elección de tema, etc.); reunión de datos (elección de fuentes, etc.); reconstrucción histórico-jurídica (comprobación y fijación de datos) y exposición de resultados (II, pp. III-LVII).

${ }^{10}$ «Los Fueros de Medinaceli», AHDE, XXXI, 1961, pp. 9-16. Estudio de las dos copias tardías que han llegado de dicho fuero, en los lugares navarros de Carcastillo y Murillo el Fruto. El primero de ellos sería una redacción del fuero no escrito de Carcastillo, que, según esta concesión de Alfonso I de Aragón, era el de Medinaceli, el cual lo vio y aseguró que era el suyo. El Fuero de Murillo el Fruto es una redacción hecha por el propio concejo de Medinaceli. Ambos textos recogidos por Muñoz y Romero. Ninguno va fechado; GG desecha las opiniones existentes sobre la fecha de emisión del fuero, deduciendo que cuando se dieron ambos textos no existía un texto del fuero, sino que se trataba de unos usos.

Respecto al rey que lo concedió, vuelva a desechar las opiniones existentes, que lo atribuían a Alfonso I de Aragón. Opina que sería obra de Alfonso VI, a fines del siglo XI, si bien el texto se habría perdido en las luchas por la ocupación de la villa. Pedro I de Aragón y Navarra, a fines de 1102, pudo haber concedido el fuero de Murillo el Fruto. Alfonso I de Aragón sí habría concedido ese fuero a Carcastillo a comienzos de 1125, siendo pedida la compulsa con el de Medinaceli en 1140. En cuanto a la segunda versión del Fuero de Medinaceli, conservado en Murillo el Fruto, entiende GG que habría que retrasarlo a 1180, atribuyéndolo a Alfonso VIII.

${ }^{11}$ «El Fuero de León. Su historia, textos y redacciones», AHDE, XXXIX, 1969, pp. 5-171. 
$\left.5^{\circ}\right)$ Historia del Fuero: fueros escritos y no escritos, cartas de fuero y refundiciones:

- los textos primarios del Fuero: la irrelevancia de los Decretos generales de Alfonso V en la Curia de León de 1017; la carta de población de León: fecha y redacción; la concesión de asilo; la ciudad como centro de la vida local; la unidad de fuero y la autoridad del concejo; la prenda y la seguridad del mercado; la carta de población y el derecho de la época; el Fuero de León: caracterización, exención de cargas, responsabilidad por homicidio, relaciones con el señor, responsabilidad por lesiones, regulación de la fiaduría, privilegio procesal de la mujer casada, el contraste del fuero con el derecho del siglo XI; a Constitución real: caracterización, establecimiento de jueces electos, determinación de las pruebas judiciales, pena del testigo falso, inviolabilidad del domicilio, perturbación del mercado, sanción, fecha y autor; ordenanzas municipales: caracterización y fecha; preceptos de origen vario; y normas sobre roturaciones y plantaciones.

- las refundiciones del Fuero: cinco refundiciones, realizadas por los encargados de la custodia de los documentos originales, gozando de la misma autoridad que éstos, luego confirmados por los reyes.

- las concesiones del Fuero.

- el Fuero en el siglo XIII: prestigio, concesiones y confirmaciones; vigencia en 1269; derogación parcial por los privilegios reales; la injerencia del cabildo catedralicio en la vida jurídica; el juicio del Libro y el Fuero de León).

$6^{\circ}$ ) Conclusiones (hechos e hipótesis; bases para reconstruir su historia; resultados de la crítica textual; textos primarios del Fuero; refundiciones).

- el texto ovetense no es la fuente común del resto de los textos.

- forman tres series: Villavicencio-Pajares, Castrocalbón-ovetense y Villafranca-Sanabria. El de Rabanal escapa a esa clasificación. Las coincidencias dentro de los grupos no lo son por haberse copiado entre sí, sino por haber tenido a la vista un mismo modelo.

- existencia de textos primarios de derecho local leonés, luego objeto de refundiciones.

- existencia de 5 refundiciones sucesivas.

$\left.7^{\circ}\right) 7$ apéndices (cotejo de ambas redacciones; preceptos concordantes entre los textos del Fuero y en los fueros de la familia) (páginas 150-171).

Temía que la novedad de sus hipótesis levantase las críticas, esperando que éstas se separasen de lo que para GG eran hechos probados. Lo novedoso no son los textos utilizados, ya conocidos entonces, sino la aplicación de métodos históricos, crítica interna y crítica textual. Esta exposición de temores del autor en las conclusiones de la primera obra en la que aplica plenamente su método estaba más que justificada; efectivamente, allí donde habla la documentación se pueden extraer conclusiones más o menos fiables, pero donde no existe certeza textual es temerario dejar volar la imaginación más allá de lo razonable, sin que el recurso a defender la hipotética existencia de textos hoy perdidos sea ninguna panacea. En cualquier caso, a nuestro modo de ver, el método utilizado era muy plausible, siempre y cuando se basase en documentos contrastables. Donde no los haya, mejor no pronunciarse. Además, esto cuadraría perfectamente con lo que, al parecer, defendía GG delante de sus discípulos, al decir que había que dejar hablar a los documentos, ya que éstos siempre tenían razón. ${ }^{12}$

\footnotetext{
${ }^{12}$ Así lo afirma Ana Barrero en «Notas sobre algunos fueros castellanos», p. 11.
} 
Pasados algunos años GG volvió a ocuparse brevemente del Fuero de León, en una breve nota de una obra ajena. ${ }^{13}$

Salvando los datos factuales que se recogen en cada uno de los distintos trabajos sobre los fueros, los demás estudios del profesor GG obedecen al mismo esquema y método. Por lo que se refiere al fuero de Llanes, de 1970, éste fue el sumario: ${ }^{14}$

$\left.1^{\circ}\right)$ Transmisión manuscrita: no se conserva el original; transmitido en carta de confirmación de 1481, donde se recogen confirmaciones sucesivas desde Alfonso XI en 1333, hasta los Reyes Católicos, incluyendo las de Enrique II, Juan II (minoría y mayoría) y Enrique IV. De acuerdo con el encabezamiento de Alfonso XI, se ha interpretado que se trataba de una concesión de Alfonso IX, en 1206, pero GG discrepa.

$\left.2^{\circ}\right)$ La carta de concesión del fuero y el fuero propiamente dicho: tal hipótesis no es convincente para GG, pues el texto está traducido al castellano y carece de las cláusulas finales; hay dos Alfonsos distintos mencionados, uno rey de Castilla y León y otro sólo rey de León. Se trata, pues, de dos textos diferentes.

${ }^{13}$ Nos referimos a El Fuero de León. Comentarios, debido al Seminario de Historia Medieval de España, dirigido por don Luis García de Valdeavellano; fue editado por la Hullera Vasco-Leonesa en 1983. La nota bibliográfica de GG en el Anuario de 1984, pp. 746-747.

Como bien se imaginaba García-Gallo, sus ideas no dejaron de producir la reacción crítica de su antiguo maestro, don Claudio Sánchez-Albornoz, como recoge el mencionado trabajo del Seminario de Historia Medieval (en sus páginas 14-16, tras exponerse asépticamente lo defendido por GG, se recogen las críticas de don Claudio, centradas en la defensa de la redacción básicamente unitaria del Fuero, sin dar crédito a las sucesivas refundiciones imaginadas por García-Gallo).

Sin embargo, en la nota bibliográfica de GG no se contesta a las críticas de don Claudio, sino que se carga contra la obra misma, tachándola de obra de divulgación, sin aportar investigación ni adoptar posición crítica; como grandes errores, en realidad, GG atribuye a la obra del Seminario la introducción de una confusión en la fecha del Fuero, que no se tienen en cuenta otros textos concedidos, que sólo sigue la edición de Vázquez de Parga, que los comentarios de los distintos capítulos no siempre explican suficientemente su contenido y que se reproducen imágenes de la época sin relación directa con el fuero. Le llama la atención que no se conozca bien la autoría del trabajo y la aportación de los distintos miembros, salvo que Rogelio Pérez-Bustamante había preparado la edición.

Como miembro de aquel Seminario creo poder aportar algunas noticias que, tal vez, sean de interés. En primer lugar, he de confesar que el tono que utilizó el profesor García-Gallo en esta nota bibliográfica, que no llega a ser siquiera una breve recensión, me causó en su día una gran estupefacción, por ser impropio de una mínima cortesía profesional; ¡qué diferente el tono utilizado años después por el profesor Sánchez-Arcilla, discípulo de GG, al comentar en su trabajo sobre los fueros leoneses las opiniones vertidas en la obra del Seminario! Este autor, por cierto, cuando quiere referirse a la autoría de los comentarios al Fuero, habla elípticamente (el autor de los Comentarios). Es evidente que el autor de los mismos no fue otro que el profesor García de Valdeavellano, que, con su proverbial generosidad, quiso hacernos partícipes de la autoría a todos los miembros del Seminario, que fuimos meros oyentes de sus ideas, en buena medida concordantes con las de don Claudio; añadir que es cierto que el profesor Pérez-Bustamante se ocupó de buscar tanto un editor como las hermosas ilustraciones que se incluyen en la obra. Por otra parte, decir que la única novedad que se introdujo en el discurso de don Luis fue a instancias de mí, a propósito del concepto de «cibera», si bien la redacción de la nota aclaratoria sobre la misma fue encargada por don Luis a otro miembro del Seminario (precepto 33). La corrección de pruebas y la elaboración del glosario final las realicé yo mismo por indicación del autor.

${ }^{14}$ «El Fuero de Llanes», AHDE, XL, 1970, pp. 241-268. 
$\left.3^{\circ}\right)$ El texto del Fuero: no resulta fácil determinar dónde acaba el texto original.

$\left.4^{\circ}\right)$ La estructura externa del Fuero: se trata de una compilación con varias fases: 1-30, 31-49, 50-62, capítulos intercalados, 66-69, 70-73 (confirmación de preceptos reales y municipales), 74 (confirmación de privilegio real) y 75 (confirmación general).

$5^{\circ}$ ) La composición del Fuero de Llanes: procede del fuero de Benavente, como expresa el texto; Gibert dice que los fueros de Llanes son mejores que los de Benavente, de los que procede, sin llegar a precisar más las concordancias. GG cree que se puede ir más allá, al menos, en 65 de los 75 que contiene.

De los primeros 49 epígrafes de Llanes, salvo $6(1,7,15,16,32$ y 47), proceden del Fuero de Parga — versión de 1225, con el fuero de Benavente ampliado, versión ensanchada del de Benavente de 1164-; las dos primeras series de Llanes (1-30 y 31-49) están tomadas de Parga. La tercera serie (50-65) es el fuero de Benavente de 1167 con sus adiciones. El resto de los capítulos probablemente proceden, según GG, también de Benavente, aunque de textos no conservados hoy.

$\left.6^{\circ}\right)$ El origen de ese Fuero: el fuero de Llanes se tomó de una compilación y refundición ya elaborada en Benavente previamente, supone GG, pues no es creíble que en Llanes tuvieran todos los materiales necesarios.

$7^{\circ}$ ) La originalidad del Fuero de Llanes respecto de sus fuentes: el texto de Llanes guarda mucha fidelidad a sus modelos.

$8^{\circ}$ ) El rey otorgante del Fuero: se trata de Alfonso IX de León.

$\left.9^{\circ}\right)$ Los elementos susceptibles de datación: las menciones conservadas son confusas o erróneas. Los dos Alfonsos mencionados serían el IX de León y el X de Castilla y León. No es posible saber a ciencia cierta quién es el monarca repoblador de Llanes, probablemente Alfonso X en torno a 1270. Se encuentran referencias a Fernando II, Alfonso IX y Alfonso X, de acuerdo con la crítica textual.

$10^{\circ}$ ) La fecha del fuero expresada en éste: expresa en Benavente, 01/10/1168, cuando reinaba Fernando II. Ese día no estaba en esa villa el rey, pero sí en diciembre, posible confusión del copista, de octob. por decemb. Si hubiera error en la transmisión del año, podría ser 1228, pues en ese fecha el rey Alfonso IX estaba en Benavente. Según GG, Alfonso X no pisó Benavente durante todo su reinado. ${ }^{15}$

$11^{\circ}$ ) Conclusiones de carácter cronológico: no es posible que fuera Fernando II; buena parte del texto debe atribuirse a Alfonso IX en 1228, si bien el preámbulo y el encabezamiento se deben a Alfonso X, tal como ha llegado a hoy.

$\left.12^{\circ}\right)$ La historia del Fuero de Llanes: se puede reconstruir con bastante precisión, según GG:

- Alfonso IX repuebla en 1228 Puebla de Llanes, fijando los términos de la anteriormente llamada Tierra de Aguilar.

- Tras llevar una vida lánguida por el peso que tenía Oviedo en la zona, Alfonso X en torno a 1270 refuerza la repoblación de la villa, junto a muchas otras de Galicia y Asturias.

— En ese momento se utilizaron los fueros refundidos de 1164 y 1167 dados a Benavente.

- El texto pretendidamente elaborado en la chancillería de Alfonso X sería para GG una falsificación, imitando una carta real, no un privilegio. Habría quedado redactado así:

a) otorgamiento de Alfonso X, en preámbulo.

b) fuero sobrecarteado de Alfonso IX en 1228, empezando por la concesión de términos (1); texto refundido de Benavente de 1164 (2-49) y 1167 (50-65), privilegio de Alfonso IX sobre solariegos y hombres de behetría (66-69), confirmación real de todo lo anterior (70), adiciones posteriores (71-73), privilegio de Alfonso IX a los clérigos (74) y confirmación de Alfonso IX en 1228 .

\footnotetext{
${ }^{15}$ Esta afirmación de GG es posible confirmarla hoy fehacientemente (Manuel González Jiménez y Ma Antonia Carmona Ruiz, Documentación e Itinerario de Alfonso X el Sabio, Sevilla, 2012).
} 
Los de Llanes aprovecharon un momento en que Alfonso XI andaba luchando con Juan Núñez de Lara para presentar el extraño documento a confirmación, que se llevó a cabo sin la presencia del notario mayor y sin las mínimas garantías para comprobar su autenticidad.

A nuestro modo de ver, el estudio del Fuero de Llanes es el más conseguido de los trabajos forales de GG, por permitir la documentación conservada un mejor despliegue del método propugnado. En cambio, los dos trabajos siguientes, que completan la mencionada cuatrilogía, no se prestan tan fácilmente al procedimiento previsto, a pesar de lo cual el avance que supuso su publicación es evidente. Por lo que se refiere al fuero de Benavente, editado en el Anuario de 1971:16

Estado de la cuestión: hasta ese momento las noticias que se tenían eran escasas y fragmentarias, a pesar de su innegable importancia en la plena Edad Media; hasta que don Julio González (Hispania, 1942) procedió a identificar Malgrad con Benavente, editó el fuero de 1167 y reunió un acopio de datos sobre su difusión.

La población de Benavente: poblada no por necesidades fronterizas, sino por motivos de política interior, debido a su ubicación geográfica. Fue poblada por Fernando II de León en 1164 en el lugar de Malgrad, donde ya existía antes un tenente real. En seguida la desidia de los primeros pobladores y la mala administración de éstos da lugar a que el rey intervenga de nuevo, otorgando el fuero de 1167, conociéndose la nueva villa ya desde 1168 como Benavente.

$\left.1^{\circ}\right)$ Los textos: el otorgado en 1164 se ha perdido. En el mismo les concedía términos y les daba normas conformes con las del Fuero de León.

- el fuero de 1167: es una confirmación del anterior, sin llegar a reproducirlo. Se conserva en un pergamino en privilegio rodado, si bien con ciertas peculiaridades, que hacen deducir a GG que este privilegio no es el original, sino que el concejo ha añadido algunos elementos como los gobernantes de la villa, a quien va dirigido el documento-, pero conservando el articulado original. Sería una refundición.

- las adiciones al fuero de 1167: se han introducido algunas adiciones aprovechando los huecos libres del pergamino.

- las concesiones del fuero de Benavente: pasados 25 años de su otorgamiento, se utiliza para la repoblación de otros lugares. En unos casos se extiende sin más el uso del fuero a otra población, sin relacionar su contenido (Mansilla, La Coruña, Burgo, Rúa, Parayas, Puentedeume, Puebla de Muro, Castropol). En otros, sí se incluye su articulado (Milmanda, Betanzos, Parga, Llanes, San Mamés, Luarca, Castillo de Salas, Buetes). Existen otros casos en que, sin decir que se trata del fuero de Benavente, se les otorgan sus preceptos, reproduciéndolos (Villafranca del Bierzo, Puebla de Sanabria).

- el cotejo de los textos (introduce un cuadro comparativo de preceptos entre siete textos: León (ovetense), Benavente de 1167, Villafranca de 1192, Sanabria de 1220, Milmanda de 1199, Parga de 1225 y Llanes de 1270). El cotejo no le permite a GG llegar a grandes conclusiones, debido a la falta de algunos documentos y a las sucesivas refundiciones de algunos otros.

$\left.2^{\circ}\right)$ Historia y redacciones de los fueros:

- el fuero de 1164: en ausencia del texto, GG identifica como propios de este fuero 7 preceptos procedentes del texto leonés, dedicados a fomentar la población de un lugar (libertad por

${ }^{16}$ «El Fuero de Benavente», AHDE, XLI, 1971, pp. 1.143-1.192. Ese mismo año, GG dio a conocer en Italia «Los problemas de edición de las fuentes del Derecho local español», Atti del Secondo Congresso Internazionale della Società Italiana di Storia del Diritto, Venezia, 1971, pp. 245-255. En julio de 1972 ponunciaría en Sigüenza una conferencia sobre «El Derecho de la Extremadura», que permanece inédita, según comenta Ana Barrero en su Fuero de Teruel, p. 27, nota 95. 
tierras poseídas en otros lugares; exención de tributos y cargas; prohibición de matar en la villa al enemigo; inviolabilidad del domicilio; ser juzgados en la villa, pudiendo apelar al rey; igualdad de fuero entre vecinos).

— la carta de fueros de León: al haberse recibido genéricamente los fueros de León, el concejo de Benavente dispuso de una copia del mismo, que no se incorporó a los suyos. En los fueros sucesivos aparece en unos (primera refundición, base de los fueros de Villafranca y Sanabria), pero en otros no (refundiciones, base de los fueros de Milmanda, Parga y Llanes).

- nuevos fueros y privilegios reales concedidos a Benavente: se trata del mencionado fuero de 1167, así como diversos privilegios, cuyos originales no han sido conservados, pero se incluyen en concesiones posteriores a otros lugares (exención de facendera a oficiales o regulación de las pesquisas; exenciones de fonsado o fonsadera; exención de responsabilidad por homicidio involuntario, cometido al corregir a discípulos, mujer o hijos).

- establecimientos del concejo: algunos escasos datos al respecto, como la consolidación del derecho de propiedad por el transcurso de tres años.

- la primera refundición y los fueros de Villafranca del Bierzo y Sanabria: se refunden privilegios reales y acuerdos del concejo, antes de 1192, como consta en el articulado de esos dos fueros.

— la segunda refundición y el fuero de Milmanda: refundición perdida, rastreable en el fondo común que poseen los fueros de Milmana, Parga y Llanes. Se basa en el perdido fuero de 1164 y prescinde del fuero de León y de los privilegios reales comentados, así como del fuero de 1167.

— la tercera refundición y los fueros de Parga y Llanes: hecha sobre la base de la refundición anterior, realizada por el concejo, que incluye 15 preceptos de origen municipal. También inserta algunos artículos de un privilegio desconocido a Benavente, otorgado por Alfonso IX.

- el fuero de Benavente y el de Llanes: el fuero de Llanes es muy similar al de Parga, si bien ambos proceden de un modelo común. Además, el de Llanes incluye el fuero de 1167 con sus adiciones, además de otras leyes sin identificar. Todo ello implicaría la existencia de una cuarta refundición.

- conclusiones (incluye esquema de transmisión de fueros, a partir del fuero de León).

$3^{\circ}$ ) Apéndices (a partir de página 1.168, hasta el final):

- Fuero de Benavente de 1164

- Carta de fueros de León comunicada a Benavente

- Fuero de Benavente de 1167

- Privilegios reales concedidos a Benavente;:

- de exenciones y pesquisas

- de nuevas exenciones

- sobre responsabilidad penal por homicidio involuntario

- Segunda refundición del fuero de Benavente

- Fuero de Benavente concedido por Alfonso IX

- Establecimientos del concejo de Benavente

Pero donde se acucia la dificultad de aplicar el método histórico-crítico es en el caso de los complejos Fueros de Toledo, según confesión del propio autor. ${ }^{17}$

Planteamiento del estudio: textos insuficientemente estudiados hasta ese momento, se trataba para GG de analizar críticamente los textos disponibles y tratar de reconstruir la historia de los mismos, lo primero factible, lo segundo hipotético.

\footnotetext{
${ }^{17}$ «Los Fueros de Toledo», AHDE, XLV, 1975, pp. 341-488.
} 
A) Estudio crítico de los textos, textos disponibles: se conservan textos directamente otorgados a Toledo y otros concedidos a otros lugares sobre la base toledana, pero que pueden no ser exacto reflejo del derecho aplicado allá.

$\left.1^{\circ}\right)$ Textos toledanos: no se conservan los textos originales de Alfonso VI y VII, ya desde antiguo. Cuando Alfonso VIII los confirma no le son presentados; en el futuro tampoco se ponen de manifiesto.

— privilegio de Alfonso VI a los mozárabes en 19/03/1101: conservado en numerosas copias posteriores, en algunos casos, muy viciadas; GG considera que es verídico y reconstruible sobre el material existente.

— privilegio «supuesto» de Alfonso VII en 1118: lo denomina «el más famoso y perdurable». Es reconstruible. No es documento real, pero sí la parte dispositiva, correspondiente a un pacto y foedus firmísimo establecido por Alfonso VI con los toledanos, castellanos y mozárabes, confirmado por el Emperador, que lo adiciona.

- fuero de francos de 1136: confirmación de fuero de Alfonso VI. Original.

- fuero secular del clero: en 1128 el primero, en 1136 el segundo.

— privilegio [falso] de exención de portazgo y alessor [décima] de 1137: para GG es una falsificación posterior.

- confirmación del privilegio de mozárabes de 1155: confirmación auténtica del privilegio de 1101, si bien ahora extendido a toda la población cristiana de la ciudad.

— confirmación del fuero refundido por Alfonso VIII en 1174: copia veraz del perdido original.

— otros privilegios de Alfonso VIII: de 1182, 1202, 1203 y 1207.

— confirmación de la segunda recopilación del fuero por Fernando III en 16/01/1222: no conservada, pero sí su confirmación en 1252. Se trata de la compilación definitiva de los fueros toledanos. Será el texto usado en la extensión del fuero a Córdoba, Sevilla, etc.

$2^{\circ}$ ) Textos no toledanos:

- fuero del castillo de Aceca, de 1102: escrito el original en árabe, se conserva la traducción castellana de 1235, para mozárabes; los remite al fuero toledano.

- fuero de Santa Olalla de 1124, perdido. Burriel ha trasladado algunos de sus artículos; era para castellanos y mozárabes.

— fueros de Escalona: en 1118 por Alfonso VII, perdido; en 1130 por los hermanos Alvarez, señores de la villa, conservado en copias posteriores, interpoladas. Partía del fuero de los castellanos de Toledo.

- fuero del castillo de Oreja: de 1139, nada tiene en común con el derecho toledano.

- fuero de Calatalifa: concedido por Alfonso VII en 1141, junto con el obispo y canónigos de Segovia y el alcaide Sebastián Díaz. Remite a los fueros de Toledo, sin especificar a cuáles.

- las reproducciones del Fuero de Toledo (Andalucía, Murcia, Alicante): Córdoba, Carmona, Cartagena, Alicante, Orihuela, Sevilla (de éste a Arcos de la Frontera, Nielba, Murcia).

- stemma de los fueros toledanos (cuadro).

B) Historia del Fuero. su reconstrucción: se trata de tres fases, primero, pluralismo jurídico, luego unificación en torno a un Fuero y, finalmente, uso del mismo como modelo para extenderlo por los nuevos lugares conquistados.

$1^{\circ}$ ) Pluralismo foral antiguo:

- la conquista de Toledo en 1085: cesión de Alcadir a Alfonso VI de la ciudad a cambio de ayuda para ocupar Valencia, sin participación de la población local.

- fuero de moros: no se conserva la capitulación, pero se les permitió seguir viviendo dentro de la ciudad, manteniendo sus propiedades y su propio derecho, con justicias privativas.

- fuero de judíos: no hubo capitulación con esta población, que, sin embargo, se mantuvo con sus propiedades, estatus libre y autoridades propias.

- fuero de castellanos: era preciso traer población del Duero o al norte del mismo para asegurar las posiciones del rey dentro de la ciudad; para atraerlos se aprueba la carta de los caste- 
llanos de 1101, de acuerdo con los buenos fueros decantados en los años del conde castellano don Sancho García. Este privilegio no recogía todos los supuestos posibles: jurisdicción al iudex y a 4 nobles castellanos; prohibición de ser prendados; privilegios de los caballeros; libertades varias (no monopolios, medianedo, no dependencia de judíos o musulmanes); penas graves contra la violencia; posible exención de portazgo.

Tras la embestida almorávide, el menor Alfonso VII confirma verbalmente los fueros toledanos de las tres comunidades cristianas, confirmación que no fue puesta por escrito.

La carta de castellanos fue renovada en 1130, ampliándola con la mención a la confirmación verbal, así como con notas marginales, lo que supuso la incorporación de nuevas cláusulas privilegiadas.

- fuero de mozárabes: no se sabe su situación antes de la conquista de la ciudad ni que fueran tratados de una forma determinada tras ésta; en cualquier caso, Alfonso VI aumentó el número de los mozárabes trayéndolos allá desde Al-Andalus. Su situación fue problemática (despojo de bienes comprados por los mozárabes de los musulmanes idos, para entregarlos a los nuevos pobladores), hasta la carta de firmeza de 1101, que no les reconocía un régimen privilegiados, salvo el de regirse por el Liber - pero en temas penales se aplicaría el derecho de los castellanos-; en lo demás, fueron igualados a los castellanos. Tenían alcaldes propios.

Cuando la oleada almohade aumenta el número de mozárabes refugiados en Toledo y otras localidades de la zona. Entonces, en 1155, Alfonso VII confirma el privilegio de 1101 a la letra.

- fuero de francos: la inmigración europea de la segunda mitad del siglo XI se canalizó hacia Toledo; tras la conquista acuden en cierta cantidad, asentándose en el arrabal de francos, en torno al Zocodover. Se desconoce si recibieron fueros especiales hasta la carta de Alfonso VII en 1136, donde se protegía el comercio. No parece que tuvieran autoridades separadas.

- fuero de clérigos: régimen privilegiado por Alfonso VII en 1128, al considerarles milicia espiritual. En 1136 se confirman las exenciones obtenidas en la época de Alfonso VI, en especial, la exención a los clérigos del arzobispado de la jurisdicción ordinaria.

$2^{\circ}$ ) Unificación de los fueros:

- fusión de los grupos de población: los tres grupos cristianos, a pesar de hablar lenguas distintas, tendieron a fusionarse, comenzando por los francos, de procedencias muy diversas, luego los mozárabes también perdieron su idioma arábigo en beneficio del castellano, que devino lengua común. A cambio, los morárabes acabarían imponiendo su derecho al resto. Esto fue un hecho ya en 1155 .

- prevalencia del Liber sobre los derechos propios de francos y castellanos: francos y castellanos abandonan su derecho, debido a la diversidad de sus respectivos orígenes geográficos, llegándose, incluso, a imponerse para la generalidad el régimen penal del Liber.

— pluralidad de jurisdicciones: a pesar de la fusión normativa, se mantuvieron las justicias separadas

- el Fuero refundido: no es el resultado de una decisión regia, sino algo patrocinado por el propio municipio, reconociendo una realidad de integración de la población cristiana. Realizado el documento con posterioridad a 1155 y antes de 1174, entre 1157 y 1169 :

1. Formación, unificación del fuero y de su jurisdicción: se designa un tribunal formado por un iudex y 10 personas elegidas entre nobles y conocedores del derecho, es decir, junto al juez había dos alcaldes, cada uno asistido por otras cuatro personas o alguaciles.

2. La unificación del estatuto nobiliario mozárabe con el castellano, su confirmación por Alfonso VIII: de origen la posición de los nobles mozárabes fue inferior a la de los castellanos; la conversión en milites a los mozárabes con caballo y armas de guerra se produce en 1101. Alfonso VIII confirma todas las normas relativas a la caballería toledana en 1174, independientemente de su origen concreto, unificándose, así, el régimen privilegiado de unos y otros. Sin embargo, este rey permitió a los castellanos invocar su derecho en sede judicial. GG desconoce hasta cuándo se siguió utilizando esta duplicidad. 
3. La pretensión de la exención de portazgo y alessor: insólito privilegio falsificado de 1178, atribuyéndolo a Alfonso VII en 1137, por el que los toledanos quedaban libres de pagar portazgo y décima regia o alessor. No obstante, el fraude resultó ineficaz.

4. Privilegios concedidos por Alfonso VIII: en 1182 exime a los caballeros de décimas reales; en 1202 eximió de pecho, posta y facendera a los que tuvieran vecindad en la ciudad y practicasen la vida militar. Poco después compensaba con distintos privilegios a la totalidad de los toledanos los dirigidos sólo a la caballería, relativos ahora al mesón del trigo o las facenderas en la ciudad a todos los que habitasen en el término de la ciudad, independentemente del señorío a que pertenecieran (1207). Además, en ese año anuló las ventas de propiedades a instituciones religiosas, salvo a la catedral metropolitana.

5. Consolidación del fuero por Fernando III (el extendido a las ciudades del sur): al confirmarlo en 1222 lo fija ya definitivamente.

6. Reacción de la nobleza toledana contra la comunidad concejil: los milites pretendían mantener su singularidad respecto al común de la ciudad, negando la existencia de un concejo y atribuyendo a Toledo una personalidad especial, nunca definida.

$3^{\circ}$ ) El derecho de Toledo y la Extremadura castellana: el hecho de que el derecho toledano se erigiese sobre la base del derecho de los mozárabes le quitó capacidad expansiva durante un siglo. Los nuevos pobladores castellanos prefieren utilizar el derecho propio en la Extremadura, siendo ocupado su lugar por otros fueros, como los de la familia de Cuenca (formulario de fueros).

- su coexistencia y fusión (Fuero de Toledo/Sevilla, etc. Fuero Real; cambio de política legislativa con Fernando III y Alfonso X).

C) Apéndices: distintos fueros y confirmaciones (pp. 459-488).

- carta de seguridad de los mozárabes de Toledo, 1101.

- fuero del Castillo de Aceca, 1102.

- fuero de Santa Olalla, 1124

— privilegio a los clérigos de Toledo, 1128.

- fuero de Escalona, 1130.

- fuero de los francos de Toledo, 1136.

— privilegio a la Iglesia de Toledo, 1136.

- fuero del Castillo de Oreja, 1139.

— confirmación de la carta de seguridad de los mozárabes, 1155.

- fuero refundido de Toledo

— confirmación del fuero refundido por Alfonso VIII, 1174.

- privilegio de exención de portazgo y alessor en Toledo, 1178.

— confirmación del fuero de Toledo por Fernando III, en 1222.

Pues bien, con los fueros toledanos puede darse por finalizada la intensa labor crítica del profesor García-Gallo — al menos, en lo que se refiere a trabajos publicados-, el cual sólo volvió a ocuparse en 1984 de la carta-puebla de Brañosera, con ocasión del Homenaje a su discípulo, José Martínez Gijón. ${ }^{18}$ Como se puede apreciar,

\footnotetext{
${ }_{18}$ «En torno a la carta de población de Brañosera», HID, XI, 1984, pp. 1-14. Aportación que encabeza el homenaje sevillano de su discípulo, José Martínez Gijón, en la que realiza un estado de la cuestión acerca de la veracidad o falsedad del tenido por más antiguo fuero castellano, que resuelve en el sentido de darla por auténtica con alguna interpolación. Se centra, especialmente, en identificar a los concedentes, lo que le lleva a plantearse la fecha real del documento. Tras un detenido estudio genealógico, se ocupa de la naturaleza jurídica de esta carta-puebla, caracterizándola como una carta ad populandum.
} 
eran muchos los temas que interesaban a GG dentro de sus preocupaciones históricojurídicas y los fueros eran uno de ellos, cuyo estudio, a pesar del esfuerzo que le dedicó, no podía pretender colmar con su trabajo personal. Por ello hubo de contar con la ayuda de sus discípulos, que, hasta cierto punto, han continuado su obra, usando o no el método histórico-crítico que propugnaba.

\section{La obra de sus discípulos}

El trabajo de García-Gallo en el ámbito de los fueros medievales se había dirigido, pues, en dos direcciones: por una parte, al estudio de fueros y grupos de fueros mediante la crítica diplomática e histórica de los mismos y, por otra, a la creación de un corpus documental donde se continuase y culminase la labor iniciada en el siglo XIX por Muñoz y Romero. Este segundo camino fue recorrido por Mari Luz Alonso y Ana Barrero, que en 1989 dieron a la estampa los Textos de derecho local español en la Edad Media. Catálogo de Fueros y Costums municipales (Madrid, 1989).

Dicha obra viene precedida de una presentación del profesor García-Gallo, gracias a la cual sabemos de la existencia de un fichero de fueros, primero en la sede del Centro de Estudios Históricos y, luego, tras la contienda civil, en el Instituto de Estudios Medievales, donde GG dice, crípticamente, que alguien había hecho uso del mismo — siendo aprovechados por algunos, sin recibir a cambio ninguna aportación-. No es posible saber a qué se podía referir. En cualquier caso, lo cierto es que tanto GG como don Luis García de Valdeavellano, en sus cátedras respectivas, se tomaron a pecho contar con un fichero de fueros; al parecer, ambos partían de los contenidos de la obra de Muñoz y Romero. Lamentablemente para don Luis, no contó con los medios ni los colaboradores, de que sí dispuso García-Gallo, para llevar a buen puerto tan importante trabajo. Según confesión del propio GG, para ello contó con un proyecto de investigación, del que curiosamente fue directora Ana Barrero, siendo colaboradores suyos tanto el propio GG como Mari Luz Alonso.

Según la misma presentación, sabemos que GG había reservado un puesto especial a José Martínez Gijón, a fin de que se encargara del estudio de la familia de los fueros de Cuenca, labor que nunca llegó a realizar, al decir del propio García-Gallo, debido al traslado de su pupilo a una cátedra lejos de Madrid. Hoy por hoy a ese «mihura» histórico-jurídico aún no ha salido ningún valiente a pararlo, templarlo y mandarlo, y ello a pesar de que ya están prácticamente publicados todos los ejemplares existentes. ${ }^{19} \mathrm{Si}$ bien es cierto que aún queda inédito en el Archivo Histórico Municipal de

Para 1979 había presentado en el Convegno di Varenna el trabajo «El derecho local y el común en Cataluña, Valencia y Mallorca en la Edad Media», Diritto comune e diritti locali nella Storia dell'Europa, Milano, 1980, pp. 229-249.

${ }^{19}$ Uno de los últimos fue mi Fuero de Sabiote; en la introducción al mismo ya comentaba que el establecimiento de un stemma de toda la familia de Cuenca sólo sería posible mediante un procedimiento informatizado, creando un programa ad hoc; el método histórico-crítico, realizado artesanalmente, tal 
Úbeda un ejemplar del fuero de la ciudad reclamado desde Cazorla, no parece que ese texto vaya a aportar grandes novedades respecto al modelo ubetense conocido; así pues, tras la reciente edición del Fuero de Andújar, se puede dar por cerrado el ciclo de edición de fueros de esa familia conquense. ${ }^{20}$

\subsection{José Martínez Gijón y sus propios discípulos}

A pesar de que el traslado fuera de Madrid del profesor Martínez Gijón había dado al traste con los planes de GG para que éste se ocupase de estudiar la familia del fuero de Cuenca en su conjunto, lo cierto es que el mencionado autor sí que realizó alguna aproximación al proceso de redacción de los textos de dicha familia, siquiera fuera parcialmente. ${ }^{21}$ Para ello se fijó en el régimen económico del matrimonio recogido tanto en los fueros conquenses editados a la altura de 1959, como en otros fueros de la Extremadura. Tras estudiar estos puntos (dote, arras y otras donaciones esponsalicias; régimen de comunidad de bienes adquiridos o ganados constante el matrimonio; régimen de unidad de bienes; régimen de «mitad»; situación del cónyuge abandonado y responsabilidad de la sociedad conyugal), pasó a definir las cuatro áreas de creación y fijación del derecho: una primera y más antigua, representada por los textos de Alcalá de Henares (FV), Brihuega, Soria, Zorita de los Canes, Madrid y Daroca; una segunda, intermedia, comprensiva de los territorios de Molina de Aragón y Uclés, donde se reelaboraría la normativa de la primera área, de forma independiente en ambos lugares; una tercera, en la zona de repoblación leonesa (un foco en Coria, Cáceres y Usagre y otro en Plasencia y Béjar), cuyo derecho estaría influenciado por el de las dos áreas anteriores; y, finalmente, el territorio de Alfambra, alfoz de Cuenca y macizo de Teruel, donde el panorama no es en absoluto unitario. Para MG esta progresión es lógica si se relaciona con el avance cronológico de la Reconquista.

Pasada algo más de una década, el autor volvió a ocuparse de la problemática del fuero de Cuenca y su familia de fueros. ${ }^{22}$ En ese estudio comienza por exponer la tesis de Ureña sobre los grupos existentes dentro de dicha familia (adaptaciones latinas de FC, adaptaciones romances del mismo, concesiones simples del FC o de alguna de sus imitaciones y redacciones con ciertas influencias del texto conquense), pasando luego a relacionar la crítica de García-Gallo (la imposibilidad de que Alfonso VIII

y como lo venimos comentando, sólo permite aproximaciones parciales, dado el volumen de información y las comparaciones a realizar.

${ }^{20}$ En la actualidad, preparo para el ayuntamiento de Alcázar de San Juan la edición del fuero de la villa, cuya cercanía al texto de Alarcón, al que estuvo poblada tras su emancipación de Consuegra, ya puso bien de manifiesto Jean Roudil. Así pues, tampoco aquí cabe esperar sorpresas.

${ }^{21}$ «El régimen económico del matrimonio y el proceso de redacción de los textos de la familia del Fuero de Cuenca», $A H D E$, XXIX, 1959, pp. 45-151.

22 «La familia del Fuero de Cuenca. Estado de una investigación científica», Atti del Secondo Congresso Internazionale della Società Italiana di Storia del Diritto, Firenze, 1971, pp. 415-439. 
hubiera concedido a fines del siglo XII el texto definitivo a Cuenca o el problema de la prelación cronológica entre dicho texto y sus presuntos derivados); de todo ello deducía la necesidad de enfrentarse al problema de esas relaciones familiares mediante una crítica textual severa y minuciosa. Como avance de la misma, $\mathrm{MG}$ procedía a resumir sus conclusiones extraídas en su artículo de 1959, ya reseñado (las cuatro áreas de formación y fijación del derecho), pasando luego a considerar las novedades introducidas tras la edición por Roudil del Fuero de Baeza y del llamado Formulario de fueros. Siguiendo a García-Gallo, MG opina que el texto baezano es una adaptación de FC con ciertas variantes y que el Formulario sería el modelo para la expansión del fuero por tierras del sur. Tras comparar el contenido del Formulario con los textos editados -en lo referente al régimen económico del matrimonio-, concluye resaltando la dificultad del estudio emprendido y fiando la resolución del mismo a un plazo no inferior a los 25 años, tiempo que había invertido Ureña en el suyo.

Por lo demás, no parece que MG ni sus discípulos se ocupasen de usar el método histórico-crítico de GG, sintiéndose más atraídos por realizar trabajos histórico-jurídicos de carácter transversal o diacrónico, sobre todo en el ámbito del derecho privado, eso sí, manejando con profusión los textos forales. Así, el propio MG, sin ánimo de ser exhaustivo, se ocuparía de las sucesiones, el matrimonio, la minoría de edad y los alimentos. ${ }^{23}$ Sus discípulos continuarían por la misma senda, así, el profesor Gacto Fernández se ocuparía, por ejemplo, de la filiación o de la viudedad, ${ }^{24}$ el profesor Merchán Alvarez de la tutela de menores ${ }^{25} \mathrm{y}$ el profesor García Ulecia del régimen económico del matrimonio y de los estatus personales de los hombres de la Extremadura. ${ }^{26}$

\footnotetext{
${ }^{23}$ Sucesiones: «La comunidad hereditaria y la partición de la herencia en el derecho medieval español», AHDE, XXVII-XXVIII, 1957-1958, pp. 221-304. Minoría de edad: «Los sistemas de tutela y administración de los bienes de los menores en el derecho local de Navarra», AHDE, XL, 1970, pp. 227-240, «Los sistemas de tutela y administración de los bienes de los menores en el derecho local de Castilla y León», $A H D E$, XLI, 1971, pp. 9-32, y «La menor edad en el derecho penal castellano-leonés anterior a la codificación», $A H D E$, XLIV, 1974, pp. 465-484. Matrimonio: «La indisolubilidad del matrimonio en el derecho histórico del Reino de Navarra», Ius Canonicum, XXV, 1985, pp. 227-360, y «Esponsales y matrimonio: su eficacia en los textos legales castellano-leoneses anteriores a Alfonso X el Sabio», Las relaciones entre la Iglesia y el Estado: estudios en memoria del profesor Pedro Lombardia, 1989, pp. 1.123-1.162. Además del mencionado trabajo de 1959. Alimentos: "Alimentos en favor de los ascendientes en el derecho medieval de Navarra», AHDE, L, 1980, pp. 207-222, «Alimentos en favor de los ascendientes en el derecho de Castilla y León», HID, VIII, 1981, pp. 171-194, y «Alimentos en favor de los ascendientes en el derecho histórico aragonés», Estudios en homenaje a don Claudio Sánchez Albornoz en sus 90 años, III, 1983, pp. 181-206. También en AHDE, LIV, 1984, pp. 295-322.

${ }^{24}$ Enrique Gacto Fernández, La filiación no legitima en el derecho histórico español, Universidad de Sevilla, 1969, y La condición jurídica del cónyuge viudo en el derecho visigodo y en los fueros de León y Castilla, Universidad de Sevilla, 1975.

${ }^{25}$ Antonio Merchán Alvarez, La tutela de los menores en Castilla hasta fines del siglo XV, Universidad de Sevilla, 1976.

${ }^{26}$ Alberto García Ulecia, Los factores de diferenciación entre las personas en los fueros de la Extremadura castellano-aragonesa, Universidad de Sevilla, 1975, y «El régimen económico del matrimonio en los derechos locales leoneses», HID, IX, 1982, pp. 165-198.
} 


\subsection{Gonzalo Martínez Díez}

Poco después de que MG iniciase su andadura en el ámbito de la Historia del Derecho, hacía lo propio uno de los más prolíficos discípulos de GG, de hecho, el padre Gonzalo Martínez Díez publicaría en 1961 su primer trabajo en el Anuario, encuadrable por su temática en el campo que nos ocupa. Se trataba de la descripción de un manuscrito medieval del Liber iudiciorum..$^{27}$

En la obra de MD se aprecia un uso relativo del método propuesto por GG, así como un gusto por el trabajo de campo, dicho sea literalmente, y por la búsqueda y edición de documentos originales, sin olvidarse de plantearse algunas de las problemáticas que preocupaban a su maestro, del que apenas le separaban trece años de edad. Comenzando por la familia del Fuero de Cuenca, en su vertiente leonesa, se ocupó tempranamente de las relaciones entre el fuero de Coria y los fueros portugueses del área del Cima-Coa. ${ }^{28}$ Treinta años después volvió a escribir unas páginas sobre

${ }^{27}$ «Un nuevo códice del Liber Iudiciorum del siglo XII», AHDE, XXXI, 1961, pp. 651-694.

- Introducción: manuscrito existente en la Biblioteca Central de la Diputación Provincial de Barcelona (ms. 944), no usado hasta ese momento por ningún investigador.

- Descripción, época y procedencia del manuscrito: redactado hacia 1100 , se hallaba anteriormente en el monasterio de Ripoll.

- Contenido del manuscrito: antología, que incluye 347 leyes fielmente.

- Recensión y familia de manuscrito representada en éste: se trata de la edición ervigiana, aumentada, denominada Vulgata. Viene a recoger un $60 \%$ del total del texto completo. Se introduce una interpolación, relativa a la inclusión del perjurio como traición. Textualmente es coincidente con el ms. de Görliz, datable entre fines del siglo XII y comienzos del siguiente.

- Criterios de selección y principios jurídico-morales reflejados de esta antología del Liber Iudiciorum: ¿Qué cuestiones omite el copista del manuscrito respecto al modelo utilizado? Lo relativo a la servidumbre, judíos y herejes, los mercaderes ultramarinos, el mandato, normas procesales, leyes militares, división de tierras entre godos y romanos, etc.

- Difusión y datación de esta antología: coincide con el ms. Paris lat. 4.792 en sus omisiones.

${ }^{28}$ «Los Fueros de la familia Coria Cima-Coa», Homenagem ao Prof. Paulo Merêa, Revista Portuguesa de História, tomo XIII, Coimbra, 1971, pp. 343-373. Se trata de retomar el tema planteado por el propio Merêa en un artículo de 1947, luego de que dos años más tarde José Maldonado editase el Fuero de Coria y plantease nuevas hipótesis sobre la relación interna de los fueros que formaban la familia de Coria y Cima-Coa: en el actual lado portugués, Castelo Bom, Castelo Rodrigo, Castelo Melhor y Alfaiates, y en el español, Coria, Cáceres y Usagre.

Para establecer la relación entre los distintos fueros, sin acudir a consideraciones diplomáticas, compara los distintos textos entre sí: los gemelos de Coria-Castelo Bom y, por otro lado, los de Castelo Rodrigo-Castelo Melhor; Alfaiates y Coria; Coria, Castelo Rodrigo y Ciudad Rodrigo; y Cáceres y Usagre.

La comparativa textual arroja este resultado para el autor: todos los fueros proceden del desaparecido de Ciudad Rodrigo, de fines del siglo XII; directamente de éste bebe el texto de Alfaiates (1209-1227); por otro lado, la misma paternidad directa tenía el perdido fuero de Castelo Rodrigo (datable en torno a 1230), del cual procederían tanto el conocido fuero de esa localidad como el de Castelo Melhor (1237). Más complicada sería la transmisión textual para el resto de los fueros: la base sería el fuero latino de Coria, datable en el primer tercio del siglo XIII, que se expandería en tres ramas: una directa, que desembocaría en el perdido fuero de Cáceres (1231-1236), del que procederían, a su vez, los fueros cono- 
el propio Fuero de Cuenca, en lo que parece el texto de una conferencia, reseñando datos históricos de la ciudad y relaciones con otros textos de la Extremadura, para concluir: «Pero creemos que es ya posible y que ha llegado la hora, cuando se ha editado casi la totalidad de los textos de la familia de Cuenca, de abordar ese estudio que nos permita dar pasos decisivos en nuestro conocimiento acerca de la génesis del más importante de todos nuestros textos forales: el fuero de Cuenca». ${ }^{29}$

Sin embargo, no era ese fuero el que le habría de ocupar sus horas de investigación, tal vez, por haber estado reservado el tema a otra persona, como ya hemos visto. Sus quehaceres en la Universidad de Valladolid — a la altura de 1970 la Facultad de Derecho de San Sebastián dependía de aquella Universidad - le llevaron a dictar en ese año la conferencia inaugural, donde prefigura la investigación que por entonces se traía entre manos: el estudio del derecho foral de las Vascongadas. En esta lección inaugural trataría, como era obligado, del derecho guipuzcoano; ${ }^{30}$ a pesar de ello, su interés iba más bien dirigido al territorio de Álava, cuyos fueros medievales recogió en un artículo del Anuario de 1971;31 este estudio le serviría de base para el primero de los dos tomos de su Historia de Álava. ${ }^{32}$ Vizcaya y Guipúzcoa quedaron para mejor ocasión, pues MD dirigió el segundo de sus extensos trabajos de recopilación de fue-

cidos de Cáceres y Usagre; otra segunda, que desembocaría en el de Castelo Bom, y la tercera, que daría lugar al texto de Coria conocido, a través de un texto romanceado, no conservado en la actualidad.

${ }^{29}$ "Contexto histórico-jurídico del Fuero de Cuenca», Studia Carande: Revista de ciencias sociales y jurídicas, VII, tomo I, 2002, pp. 181-195. La cita copiada, en la última de esas páginas.

${ }^{30}$ Aproximación a la Historia jurídica guipuzcoana (Lección inaugural del curso 1970-1971 de la Facultad de Derecho de San Sebastián - Universidad de Valladolid), San Sebastián, 1970, 13 pp. Hitos de una historia: $1^{\circ}$ ) la concesión de Fuero a San Sebastián por Sancho el Sabio, en 1180. Zona bajo dominación navarra. $2^{\circ}$ ) De la «Tierra al villazgo»: de fines del siglo XII a 1397. De la organización por caseríos y aldeas a la municipalización. $3^{\circ}$ ) Del villazgo a la provincia: en 1397 nace la Hermandad de villas de Guipúzcoa, 24 localidades que venían a ocupar el solar de la actual provincia. Su organización sería fundamental para luchar contra los banderizos. $4^{\circ}$ ) De provincia a Guipúzcoa: los tres siglos modernos. La provincia se reúne en dos Juntas semestrales, contando con una Diputación permanente todo el año. Y $5^{\circ}$ ) De los fueros al concierto económico: de las guerras carlistas a los conciertos económicos. 31 «Alava: desarrollo de las villas y Fueros municipales (siglos XII-XIV)», AHDE, XLI, 1971, pp. 1.0631.142. Tras tratar de los antecedentes previos, relaciona los fueros conservados, desde el de Salinas de Añana, de 1140, al de Monreal de Zuya, de 1338, en total, 19 fueros; que completa con otros cuatro más, así como con otros siete que considera que nunca existieron. Termina el largo estudio con una recapitulación y el apéndice documental.

${ }^{32}$ Alava Medieval. I. El Condado y las tenencias alavesas (711-1200). Villas y fueros municipales (siglos XII-XIV), Vitoria, 1974.

$\left.1^{\circ}\right)$ El condado y las tenencias (comentario meramente histórico): Alava en la órbita astur (711-932): de las campañas de Alfonso I a la crisis política en Alava y Castilla. Fernán González y sus descendientes, condes de Alava (932-1029): de la política de doña Toda sobre Alava a Alava bajo los descendientes de Fernán González. Alternancia navarro-castellana (1029-1200): de Sancho el Mayor de Navarra a los últimos años navarros en Alava.

$2^{\circ}$ ) Villas y fueros municipales (siglos XII-XIV): fueros comentados, desde el de Salinas de Añana (1140) al de Monreal de Zuya (1338), incluyendo otros fueros y otros que nunca existieron. Documentación: edición de toda la relación de fueros. 
ros locales al territorio de la actual provincia de Santander, ${ }^{33}$ trabajo que sería recogido de inmediato como libro. ${ }^{34}$ Años más tarde, coincidiendo con la celebración del centenario del Fuero de Laredo, publicó sendos artículos en las actas del Congreso que se reunió en la villa pejina, uno dedicado a la transcripción del texto foral ${ }^{35} \mathrm{y}$ otro al origen histórico y al régimen jurídico de las villas marítimas de Castilla. ${ }^{36}$

El tercer territorio sobre el que MD proyectó su labor de recopilación de textos forales fue La Rioja. ${ }^{37} \mathrm{He}$ aquí el esquema del trabajo:

Introducción: tercer trabajo de este tipo, tras Alava y Santander; territorialmente definido como el antiguo Reino de Nájera.

$\left.1^{\circ}\right)$ Fueros y privilegios de Canales de la Sierra: fueros apócrifos (fueros de 923 y 934 y confirmaciones apócrifas de Sancho Garcés, entre fines del siglo X y comienzos del XI, y de Fernando I en 1056); y noticias de los fueros auténticos: exención de pechos de Alfonso VIII, regulación de la prueba del homicidio, de Alfonso X (1255) y privilegio de Sancho IV, prohibiendo la entrada del merino real (1293).

$3^{\circ}$ ) Conclusiones: hasta 1134, fecha de la desintegración del reino castellano-navarro-aragonés de Alfonso I, no se inicia el proceso de urbanización del territorio alavés; será Sancho el Sabio el gran impulsor de la erección de núcleos urbanos, merced a la concesión del fuero de Logroño a buen número de lugares, política continuada por Sancho el Fuerte y, tras la incorporación de Alava a Castilla, por Fernando III y Alfonso X, momento éste último en que se empieza a utilizar para el aforamiento el Fuero Real.

${ }^{33}$ «Fueros locales en el territorio de la provincia de Santander», AHDE, XLVI, 1976, pp. 527-608.

Introducción: justificación de su tratamiento unitario como territorio histórico anterior a la división provincial de Javier de Burgos, esto es, la Montaña de Burgos. Comenta que es el segundo de este tipo de trabajos suyos, tras el de los fueros de Alava, publicado en el Anuario. El criterio que utiliza en la elección de textos es amplio, incluyendo cartas de inmunidad, cartas vecinales, fueros municipales, cartas de asentamiento y fueros comarcales.

$\left.1^{\circ}\right)$ Cartas de inmunidad: fuero apócrifo de Cervatos (02/03/999); carta del monasterio de Santillana (19/03/1045); carta del monasterio de Santoña (1047) y confirmación apócrifa (1122); privilegio a los pobladores de San Andrés de Ambrosero al incorporarse a Santoña (1136); y carta apócrifa de Cillaperriel de Iguña (reinado de Alfonso VII)

$2^{\circ}$ ) Carta vecinal: privilegios a los vecinos de Baró y San Martín (1159).

$\left.3^{\circ}\right)$ Fueros municipales: fuero de Castro Urdiales (10/03/1163); fuero de Santander (11/07/1187); fuero de Laredo (25/01/1200); fuero de Santillana (13/10/1209); y fuero de San Vicente de la Barquera $(03 / 04 / 1210)$.

$4^{\circ}$ ) Cartas de asentamiento: Corera, Palacios, Sísnega, Pieza, Casares y Maestro de Ferrar (siglo XIII).

$\left.5^{\circ}\right)$ Fueros comarcales: fueros del Valle de Toranzo y fuero consuetudinario de Campoo.

Apéndices (pp. 575-608).

${ }^{34}$ Fueros locales en el territorio de la provincia de Santander, Madrid, 1976.

${ }_{35}$ «El Fuero de Laredo: transcripción», El fuero de Laredo en el octavo centenario de su concesión, Santander, 2001, pp. 31-44. Tras un breve comentario sobre las copias existentes del texto, se incluye la transcripción del fuero de 1200, añadiendo dos privilegios de Fernando III, uno de 1221 eximiendo a los laredanos de pagar portazgo en Medina de Pomar y otro de 1242 prometiéndoles no enajenar ni la villa ni sus aldeas a ningún poderoso, en agradecimiento por la defensa hecha de la misma.

${ }^{36}$ «Las villas marítimas castellanas: origen y régimen jurídico», El fuero de Laredo ..., pp. 45-86.

${ }^{37}$ «Fueros de La Rioja», AHDE, XLIX, 1979, pp. 327-454. 
$2^{\circ}$ ) Cartas vecinales de época navarra (922-1075): Cirueña (972); Villanueva de San Prudencio (1032); dehesas de Madriz (1044); Serna de San Vicente (1060); San Andrés de Jubera (1062); Longares (1063); y San Anacleto (1065).

$3^{\circ}$ ) Los grandes fueros de Alfonso VI (1076-1109): Nájera (1076) y Logroño (1095).

$\left.4^{\circ}\right)$ Los fueros de Alfonso el Batallador (1109-1134): Calahorra (1110-1114); Viguera (11091134); carta vecinal de San Martín de Berberana (1121); carta vecina de Alesón (1123); y fuero de Cornago (1124, 1125 y 1129).

$5^{\circ}$ ) Los fueros de Alfonso el Emperador (1134-1157): Entrena recibe fuero de Logroño y Villanueva de Anguiano recibe fuero de Matute (1149).

$6^{\circ}$ ) Los fueros de Alfonso VIII (1158-1214): cartas vecinales de Cihuri y Pauleja (1168); fuero de San Vicente de la Sonsierra (1172); fuero de Ocón (1174); privilegio de los collazos de Santa María de Valcuerna (1180); fueros de Santo Domingo de la Calzada (1187 y 1207); fuero de Haro (1187); fuero de Navarrete (1195); y cesión de derechos reales en Torrecilla de Cameros (1197), por Alfonso VIII al monasterio de Santa María de Nájera.

$7^{\circ}$ ) Los fueros del siglo XIII (Alfonso X): fuero de Briones (1256) y segunda carta vecinal de Longares-Albelda (1264).

$8^{\circ}$ ) Los últimos fueros del siglo XIV: fuero comarcal del Valle de Ojacastro (1312) y carta vecinal de Oriemo (1316).

$9^{\circ}$ ) Otras menciones forales: fuero de Viguera; fuero de Clavijo; y supuesto fuero de Arnedo.

Recapitulación: 11 cartas vecinales entre 972 y 1264; 10 villas con fuero breve, 7 de ellas a fuero de Logroño y el resto los de Nájera, Ocón y Haro, todas entre 1076 y 1256; todos con carácter mercantil, salvo el de Nájera; además, un fuero comarcal tardío, a Ojacastro, y las normas de la aljama de Haro. También hay seis menciones a ordenamientos locales consuetudinarios.

Apéndices (pp. 388-454)

Dentro de los fueros riojanos destaca por su importancia el de Logroño, que llegaría a ser modelo para la repoblación de esa misma zona y de las de sus alrededores, implicando, además de La Rioja, a Navarra, Vascongadas y Cantabria; MD dedicó un denso trabajo a la configuración de este fuero, haciendo descansar sus ideas sobre elementos eminentemente históricos. Relacionamos a continuación con detalle el íter seguido por el autor en este estudio: ${ }^{38}$

— La Rioja en el ámbito de la mozarabía, 714-922: la conversión al Islam del conde Casio y de parte de la población cristiana produce que en el territorio controlado por sus descendientes, los Banu Qasi, apenas se den movimientos humanos, conservando la convivencia bajo el nuevo poder de muladíes y mozárabes, con sus respectivos códigos legales.

— La Rioja se reincorpora a la Cristiandad hispánica: a partir de 922 la presión de leoneses y navarros hace que el territorio quede bajo soberanía cristiana, que se adjudica el rey de Pamplona Sancho Garcés I.

- Aportación navarra a la tradición mozárabe riojana: el derecho de los mozárabes, de los muladíes vueltos al cristianismo y de los nuevos pobladores navarros y alaveses tiende a fundirse bajo la influencia del Liber. Las fuentes conservadas para este período son casi inexistentes o directamente apócrifas.

— Dos cartas forales del siglo X apócrifas: lo son los fueros de Canales (934) y Cirueña (972).

- Seis cartas vecinales del siglo XI, 1032-1065: desde la de Villanueva del Pampaneto a la

${ }^{38}$ «El Fuero de Logroño y la tradición jurídica riojana», Actas de la reunión científica «El fuero de Logroño y su época», Logroño, 1996, pp. 231-256. 
de San Anacleto, junto a Albelda. Sólo representan una mínima parte de los cientos de privilegios que debieron de existir.

- El Reino de Nájera en el ámbito del Reino leonés, 1076: en ese año, tras el asesinato de Sancho IV en Peñalén, Pamplona se coloca bajo la obediencia del rey de Aragón, en tanto que Nájera y Alava — con todas las Vascongadas - se inclinan por Alfonso VI. A partir de ese momento el derecho tradicional de la Rioja se pone por escrito, dado que el monarca leonés promete preservar los derechos tradicionales. El fuero de Nájera no recoge sino el derecho tradicional de La Rioja.

- Clases sociales y autoridades locales en el fuero de Nájera de 1076: dos grupos, infanzones y villanos, además de judíos y musulmanes. No existe un concejo desarrollado, tan sólo los hombres del rey (tenente, vicario y juez), así como los alcaldes del mercado y de las aldeas. El concejo sólo nombraría dos sayones.

- Otras regulaciones del mismo fuero de Nájera: caloñas por homicidios o lesiones; fonsado y otras prestaciones militares; pecho, aposento; libertad de comprar y vender vituallas o de salir a vendimiar; protección del ganado, etc.

- Del fuero de Nájera al fuero de Logroño: sobre el derecho tradicional riojano se proyecta, a partir de 1076, la influencia del castellano. A través del camino de Santiago aparecerán nuevos burgos de francos.

- El fuero de Logroño y el derecho tradicional: en el texto logroñés se rompe la distinción entre infanzones y villanos, siendo todos iguales; se incorporan normas especiales para la población franca y se eligen entre los vecinos alcaldes, merino y sayón. La autonomía concejil para nombrarlos llegaría más tarde. Se suprimen también malos fueros y prestaciones personales, así como la mañería y la caloña por el homicidio de autor desconocido. Se completan esas normas privilegiadas con la capacidad de apropiarse los baldíos y utilizar las aguas, así como la libertad de construir molinos, pero no hornos.

- Garantías procesales y protección del comercio en el fuero de Logroño: salvaguarda de los domicilios, prestación de fianzas para evitar la prisión, paz de la villa y paz del mercado. Así como normas para proteger el tráfico mercantil.

- Las diversas ediciones del fuero de Logroño: no se conserva el original, ni copias del mismo; sólo bajo Alfonso VII se redactó un documento parecido, pero no similar al original, que fue confirmado por Sancho III de Castilla en 1157 y Sancho el Sabio en 1168, que finalmente fue confirmado por Pedro I en las Cortes de Valladolid de 1351; los representantes de Vitoria aprovecharon la ocasión para hacerse con una copia de la confirmación, del que proceden las ediciones modernas, muy numerosas desde el siglo XIX.

- La transmisión manuscrita del fuero de Logroño: todas las ediciones, en suma, proceden de la copia de un escribano concejil de Logroño efectuada en tiempos de Alfonso el Emperador, teniendo a la vista el original; nada impide que cometiera errores o añadiera algo de su cosecha. Contiene, eso sí, algunos anacronismos.

- Fecha fáctica en el fuero de Logroño ¿1092?: MD rechaza esa fecha por no ser compatible con hechos históricos conocidos.

— Fecha más probable, año 1095: se inclina por ésta, aunque la de 1092 no es claramente desechable.

El cuarto y último territorio que mereció el interés compilador de MD fue el de la actual provincia de Burgos. ${ }^{39}$ De nuevo sigue el mismo sistema expositivo, encuadrando en coordenadas cronológicas y temáticas los distintos textos forales, de acuerdo con el siguiente esquema:

\footnotetext{
${ }^{39}$ Fueros locales en el territorio de la provincia de Burgos, Burgos, 1982.
} 
$\left.1^{\circ}\right)$ Época condal:

- cartas vecinales (contratos agrarios): cartas de inmunidad de Javilla (941), de Rezmondo (969), de Covarrubias (978), de Nave de Albura (1012), de Berbeja, Barrio y San Zadornil (c. 1012), de Grisaleña y otras muchas villas donadas a San Millán. Citas forales impropias: San Julián del Monte (964) y Cardeña (972).

- el único fuero condal: Castrojeriz (974).

- fueros apócrifos: Lara, Canales, Peñafiel, Melgar y Salas.

$2^{\circ}$ ) De la época condal a los fueros de francos:

— privilegios de inmunidad o de coto: Villafría y Orbaneja (1039), Villariezo (1042) y el dominio del monasterio de Oña (1066).

- fueros vecinales: Cuevacardiel y Villalmóndar (1052), Hospital del Emperador en Burgos (1085), Villaespasa y Rucepos (1089) y Fresnillo de las Dueñas (1095).

$3^{\circ}$ ) Los primeros realengos (siglo XII a Alfonso VIII): carencia en el siglo XI de núcleos urbanos, sólo al sur del Duero aparecen las Comunidades de villa y tierra, generadoras del derecho de Extremadura.

Fueros de Vallunquera, Olmillos de Sasamón e Isar (1102); Burgos: extensión a 54 aldeas de sus alfoz (1103-1152). Fuero de Alfonso I: Castil de Peones y Belorado (1116); de Briviesca, por Alfonso VII (1123); de Villadiego (1134); de Villalbilla (1135); de Lara, por Alfonso VII (1135); de Santo Domingo de Silos (1135); de Los Balbases (1135); de Atapuerca (1138); de Roa (1143); de Pancorbo (1147); de Lerma (1148); de Cerezo de Río Tirón (1151). Fuero abacial de Covarrubias, Mecerreyes y Barbadillo del Pez (1148). Fueros señoriales de Tardajos (1127 y 1147). Noticias de otros fueros de Alfonso VII: Jaramillo Quemado (1128) y Sotresgudo (1127-1157).

$\left.4^{\circ}\right)$ Fueros de francos (1116-1236): Miranda (1117), Medina de Pomar (1181), Arganzón (1191), Frías (1202), Ibrillos (c. 1199) y Santa Gadea del Cid (1214-1236).

$\left.5^{\circ}\right)$ Fueros y privilegios del reinado de Alfonso VIII (1158-1214): en el reinado del Emperador, tras su coronación en 1135, la vida municipal recibe un fuerte impulso, mediante la concesión de fueros locales; con la atribución de importantes términos a Cerezo, Miranda, Lara y Lerma, y por la implantación de una generosa autonomía municipal, luego continuada por Alfonso VIII, que extenderá esos beneficios a muchos otros poblados.

— Fueros a realengo: Belbimbre y sus barrios (1187), Muñó y Pampliega (1209), apócrifo de Amaya y extensiones de fueros: el de Castrojeriz a Valdemoroy Quintanilla (1183); el de Burgos al Hospital del Emperador (San Pedro de Barrioeras) (1194) y a Belorado (1200) y el de Logroño, en algunos preceptos, a Mijangos y Criales (1209).

- Fueros a abadengos o señoríos: Hospital de Valdefuentes (1187), Santo Domingo de Silos (1209), Villaverde-Mogina (1190-1193) y San Juan de Cella (1209), extensión del régimen local de Villafría, Orbaneja y San Martín al abadengo de Cardeña (1190) y confirmación del fuero del Arroyal (1103).

- Fueros señoriales: Madrigal (1168), régimen jurídico de los vasallos de Oña y Vallegera (siglo XII).

- Cartas de inmunidad y otros privilegios: concesión de coto inmune y exención de prestaciones económicas y personales. Cartas con privilegios, pero sin referencia al coto.

$6^{\circ}$ ) Últimos fueros burgaleses:

- Fueros del reinado de Fernando III: época de máximo desarrollo de los fueros locales, pero siguiendo la política heredada de Alfonso VIII. Privilegios: Burgos, Hospital del Rey en Burgos, Pancorbo, Lences. Cartas señoriales: Cerceda (1218), Las Quintanillas (1219), Cascajares de la Sierra (1224) y Rioseco (1230)

- Alfonso X y su nueva época: fuero de Treviño (1254); Fuero Real a Burgos (1255); Alfonso $\mathrm{X}$ y los fueros de Burgos (1256-1279): al FR se añaden privilegios concedidos a las villas de la Extremadura castellana, de Soria a Trujillo. Fueros de abadengo: Cañizar de Amaya (1257) y Bentretea (1257 y 1263). 
- fueros de sus sucesores: derecho de la ciudad de Burgos: regulaciones de Sancho IV, Fernando IV y Alfonso XI. Fuero de Briviesca (1313): único fuero extenso de toda Castilla, salvo el FR, del que es una adaptación. Privilegios y cartas municipales tras 1284: Nofuentes, Roa, Vadocondes, Muñó respecto a Burgos y vasallos del Hospital de Villafranca de Montes de Oca.

Apéndice documental (pp. 117-221).

Conclusiones: en el siglo IX sólo consta la carta de Brañosera; en el X sólo algunas cartas de inmunidad; en el mismo período condal sólo el fuero de Castrojeriz; en el siglo XI penetración de fuero de francos desde Logroño, cartas de coto y algunos ordenamientos breves. Notoriedad de los fueros de la ciudad de Burgos. Alfonso VII el gran dinamizador, continuado por Alfonso VIII. Apertura de una nueva época con Alfonso X.

Como se puede apreciar, se trató de un trabajo ímprobo, intentando recopilar todos los materiales forales subsistentes en la zona nuclear castellana y sus aledaños geográficos, sin desdeñar entrar a discriminar la autenticidad, falsedad o el carácter interpolado de los textos. Sin duda, puede decirse que, en el ámbito que nos ocupa, estas compilaciones territoriales de fueros locales fueron una de las dos grandes líneas de investigación seguidas por MD.

No obstante, el autor se ha ocupado de otros textos, ya con un carácter más específico: así, en 1992 pergeñó un extenso trabajo sobre «La tradición manuscrita del Fuero de León y del Concilio de Coyanza»; ${ }^{40}$ también, con ocasión del homenaje a don Claudio en sus 90 años, presentó un breve estudio sobre el fuero del lugar vallisoletano de Mojados. ${ }^{41}$ Sin salir del ámbito castellano, MD siguió también los pasos de GG, al tratar del texto de Brañosera, donde se puede decir que aplicó el método propugnado por su maestro. ${ }^{42}$ Fuera del Reino castellano, el autor se ha preocupado, en el ámbito

${ }^{40}$ El Reino de León en la Alta Edad Media. II. Ordenamiento jurídico del Reino, León, 1992, pp. 117-184. Sobre dicho Concilio, véanse las páginas escritas por MD en este mismo volumen de los Cuadernos.

${ }^{41}$ «Los fueros inéditos de Mojados», Estudios en homenaje a don Claudio Sánchez-Albornoz en sus 90 años, Buenos Aires, 1983, II, pp. 453-467. Lugar vallisoletano, situado entre las comunidades de Portillo y Olmedo, perteneció al señorío de los obispos de Palencia, primero, y, luego, Segovia. Recibió fuero en 1176 del obispo Raimundo, conteniendo 23 disposiciones (texto inédito hasta el momento). Tras pasar por trueque a manos del magnate Tello Pérez en 1181, recae su señorío en el diocesano segoviano ese mismo año. Mientras tanto el fuero de 1176 siguió vigente hasta la nueva carta foral de 1293, aclarando el conjunto de las prestaciones debidas por los vasallos de Mojados (sernas, infurción, yantar, así como pecho, pedido y fonsadera).

42 «El primer fuero castellano: Brañosera, 13 de octubre de 824», AHDE, LXXV, 2005, pp. 29-66.

- Brañosera en el Condado de Castilla y Reino de Oviedo: importante por ser el texto más antiguo conservado.

- Transmisión manuscrita del fuero de Brañosera: conservado a través de las confirmaciones de Gonzalo Fernández en 912, Fernán González en 968 y Sancho García en 998, en el archivo de San Pedro de Arlanza. Hoy sólo persisten dos copias del siglo XVIII en el monasterio de Santo Domingo de Silos. También contamos con una copia impresa en 1615.

- Texto crítico de la carta-puebla de Brañosera: reconstruye el texto a partir de la primera copia de Silos, debida al padre Liciniano Sáenz.

- Dudas acerca de la autenticidad de la carta-puebla de Brañosera: por la inclusión de algunos anacronismos, en especial, de carácter institucional (montazgo, tributo, infurción, vigilias, anubda); por ello 
aragonés, de las Observancias del Reino de Aragón ${ }^{43}$ y de los Fueros de Aragón ${ }^{44}$ y en el área valenciana, de sus fueros comparados con otros contemporáneos. ${ }^{45}$

Si la compilación de textos forales en las áreas alavesa, riojana, cántabra y burgalesa ha sido uno de las dos grandes líneas de investigación y edición seguidas por Martínez Díez, la segunda, a nuestro modo de ver, sería el Fuero Real alfonsino y sus relaciones con el Fuero de Soria. Ya en 1969, con ocasión de un trabajo preparado para unas oposiciones, MD se planteó si eran ciertas las hipótesis sustentadas por don

no puede ser original, sino un texto interpolado, pero no anterior al siglo XI, según la hipótesis planteada por GG. Como éste, MD opina que es un texto interpolado, pero no falso ni apócrifo.

- Datación de la carta-puebla: el autor defiende la autenticidad de la fecha impresa en la carta-puebla, a pesar de las interpolaciones.

- Algunas interpolaciones en el texto de la carta-puebla: distingue dos tipos de ellas, unas cultistas en el encabezamiento y otras de carácter institucional.

- Naturaleza jurídica de la carta de Brañosera: siguiendo a GG, entiende que se trata de una cartapuebla, otorgada por el conde como delegado del rey sobre tierras de dominio público.

- Los ascendientes del conde Fernán González según el fuero de Brañosera: vital para conocer dicha ascendencia. MD reconstruye con estos datos la genealogía del gran conde.

- Sobre los signos de otorgantes y confirmantes de la carta-puebla: estudio redactado por Félix Martínez Llorente.

${ }^{43}$ Observancias del Reino de Aragón de Jaime de Hospital. Introducción y texto crítico, Zaragoza, 1977, y «Dos colecciones de Observancias de Aragón», AHDE, XLV, 1975, pp. 543-594.

${ }_{44}$ «En torno a los Fueros de Aragón de las Cortes de Huesca de 1247», AHDE, L, 1980, pp. 69-92. Este trabajo versa sobre la autoría de Vidal de Canellas respecto al Código de Huesca, que MD niega, atribuyéndola a un forista práctico de estilo seco y conciso; piensa, incluso, que la intervención de Vidal en la traducción y ordenación de los Fueros de Aragón es una posibilidad muy improbable.

45 «Los fueros valencianos en relación con otros fueros coetáneos», En torno al 750 aniversario: antecedentes y consecuencias de la conquista de Valencia, Valencia, 1989, I, pp. 379-393.

- Los fueros en la creación de un Reino: Valencia representa un caso excepcional en la historia jurídica de las Españas medievales, no quedando definido como reino hasta 1238, de hecho, los pueblos castellonenses aforados entre 1232 y 1235 reciben textos a fuero de Zaragoza, de los nobles aragoneses, o de acuerdo con las Costums de Lérida, en este caso de mano de las Ordenes Militares.

En 1238, al recibir la ciudad de Valencia, añade Jaime I a sus títulos el Reino de Valencia. Lo novedoso es que en 1239 o 1240 el monarca conceda a la ciudad y a todo su Reino unas Costums. La institucionalización del Reino aún tardará un siglo en completarse.

- La unificación jurídica del Reino: hasta 1240 se había concedido fuero de Zaragoza a 17 localidades y la Costum de Lérida a 6. A partir de 1240 la Costum de Valencia se extenderá a 61 lugares, antes de 1300 , y a 17 más en el siglo XIV.

Aun así, la presión aragonesa hará que se extienda el derecho zaragozano a 31 concejos tras 1240 . Antes de 1275 el derecho catalán se utilizará en contadas ocasiones (4 según Costums de Lérida, una al texto barcelonés y otra al de Tortosa). Todo ello es fruto de la resistencia de los nobles aragoneses a la política unificadora del Rey, hasta la transacción realizada por Alfonso IV en las Cortes de 1329-1330, al conceder las jurisdicciones alfonsinas. Así, la mayoría de las localidades de fuero aragonés lo abandonaron para acogerse al valenciano. La liquidación del derecho de Aragón en Valencia sólo se alcanzará en las Cortes de 1626.

Así, los Furs jugarán un papel parecido al de los Usatges en Cataluña, los Fueros de 1247 en Aragón, El Fuero General en Navarra y las Partidas en Castilla. 
Galo Sánchez, editor del fuero soriano, en relación con la prelación entre ambos textos y sus conexiones con el Fuero de Cuenca. ${ }^{46}$

— Introducción: recuerda la tesis de don Galo de que el FS es una de las fuentes del Fuero Real, algo rebatido por Gibert. Más tarde don Galo acepta que Alfonso VIII no pudo ser el monarca que concediese el FS extenso, asignando su autoría al concejo, sin embargo, mantiene que el FS extenso es fuente del FR.

- El Forum Conchae fuente del Fuero de Soria: MD aborda el problema con ocasión de unas oposiciones. El Fuero de Cuenca es claramente fuente del FS extenso (137 capítulos de FC incorporados en 120 de FS), no obstante, entre los 150 preceptos sorianos, supuestamente tomados por el FR, no hay referencia alguna al FC, lo que estadísticamente es algo extraño. Es más, los escasos preceptos relacionables no venían tomados en FR de FC, sino del Liber. Todo esto tendría encaje si se diese por buena la hipótesis de Gibert, de que el FS es deudor de FR y no al contrario. Así pues, entiende MD que el FS extenso está compuesto de 120 leyes procedentes de FC, 150 de FR y el resto (307) de fuentes no identificadas.

- El Liber Iudiciorum en el Fuero Real y en el Fuero de Soria: don Galo opinaba que las fuentes del FS fueron FC y Liber; sin embargo, para el autor es más plausible que las referencias al Liber en FS proceden de texto latino de aquél tomado como referencia para redactar el FR y a través de éste en FS.

Casi cuarenta años más tarde, MD volvió sobre el tema, reafirmándose en sus opiniones iniciales: ${ }^{47}$

— La Tierra de Soria: un prolongado vacío poblacional: desinterés por repoblar la zona hasta 1106.

- Alfonso I el Batallador, soberano de Soria de 1119 a 1134: este monarca navarro-aragonés repuebla Soria en 1119, reteniéndola hasta su fallecimiento en 1134.

- El Fuero breve de Soria: conservado en una copia parcial del mismo, desaparecida en Sigüenza durante la guerra civil. El copista del siglo XIII sólo se ocupó de transcribir lo relativo a los términos del concejo y normas relativas a los clérigos. Iba fechado en marzo de 1120, al poco de iniciarse su repoblación. Fue confirmado por Alfonso VII.

- Nueva confirmación y ampliación del Fuero breve de Soria en 15/04/1143: se asignan nuevos términos, se exime a los vecinos de montazgo, así como de portazgo en el camino de Deza a Valencia, y concede a Hinojosa como aldea.

- El Fuero extenso de Soria, la datación del profesor Galo Sánchez: conservado en dos códices, en el archivo municipal soriano y en la Biblioteca Nacional de Madrid, aparte de otras

- Les Furs y la potestad legislativa de los Reyes: Jaime I es el primer rey aragonés que reclama para sí en exclusiva la capacidad legislativa, de acuerdo con los principios del derecho romano. Los privilegios de Mallorca de 1231 y la Costum de Valencia en 1240 suponen un desbordamiento de la política tradicional, pues se legisla más para un Reino que para una localidad. Cuando en 1261 Jaime I jure mantener el derecho valenciano estará realizando un acto paccionado con el Reino, por cuanto lo hizo a cambio de percibir una cantidad de las Cortes. En los demás reinos hispánicos no se produce nada similar.

- Les Furs y la Recepción del Derecho Romano: la principal fuente de los Furs será el derecho de la Recepción, tanto en la forma como en el fondo, concretamente, Codex, Digesto e Instituta del Corpus Iuris justinianeo.

${ }^{46}$ «El Fuero Real y el Fuero de Soria», AHDE, XXXIX, 1969, pp. 545-562.

${ }^{47}$ «El Fuero de Soria: génesis y fuentes», AHDE, LXXVI, 2006, pp. 9-32. 
copias. En su datación don Galo yerra al situar su concesión entre 1189-1214, afirmando, pues, que sería anterior al Fuero Real. El error procede de considerar que el Fuero de Soria concedido a Deza en 1214 era el fuero extenso, cuando, en realidad, era el breve o se hablaba genéricamente.

- Afirmaciones de los profesores Alfonso García-Gallo y Rafael Gibert: GG rebate a don Galo en tres puntos (no es seguro que el fuero conocido haya sido otorgado por un monarca; es obra del siglo XIII y la concesión del derecho de Soria a Deza no es indicativa). Gibert, por su parte, situó el Fuero de Soria como dependiente del Fuero Real.

- El Fuero de Cuenca, fuente del de Soria, desconocido para el Fuero Real: acertó don Galo al afirmar que el Fuero de Soria había tomado 137 leyes del Fuero latino de Cuenca, incorporándolas en 122 de sus artículos. MD descubre que nada hay del texto conquense en el Fuero Real.

- El Fuero de Soria es posterior al Fuero Real, la datación: esta sería la conclusión de todo lo anterior. Como afirmaba Gibert, los 150 capítulos comunes a ambos fueros proceden del Fuero Real; los redactores de éste no usaron como fuentes ni el Fuero de Cuenca ni el de Soria. Así, según MD, 143 capítulos del FS procederían del FR, 122 del Fuero de Cuenca y los 312 restantes de otras fuentes (derecho consuetudinario propio, usos jurídicos y jurisprudencia de la justicia local). Es más, los textos inspirados en el Liber proceden también del FR, no del Liber. Concluye MD que debió de redactarse localmente tras 1274.

- El derecho concejil de Soria recogido en el Fuero extenso de Soria: expresa la necesidad de reeditar el FS y determinar las fuentes utilizadas en su realización, especialmente qué textos de la familia conquense se manejaron. También sería interesante determinar el origen de los 312 preceptos de paternidad desconocida (dedicados en buena medida a la autonomía municipal), así como la vigencia posterior del fuero.

Y es que entre ambos trabajos MD había realizado una ingente labor investigadora en torno al Fuero Real, para preparar su edición crítica ${ }^{48}$ Esa edición venía precedida de un estudio introductorio, desarrollado en nueve puntos:

1. Hacia una nueva edición del Fuero Real (sobre 41 piezas)

2. Las ediciones impresas del FR (19 desde la de Montalvo, Sevilla 1480-1484)

3. Transmisión manuscrita y estructura del FR («la relación entre ellos no es la de descendientes, sino la de colaterales, como procedentes de un lejano modelo común o arquetipo», sin embargo, los 35 códices coinciden en lo fundamental, p. 23).

4. Códices y fragmentos de FR: 36 códices castellanos, 2 códices portugueses, códice adaptado de Briviesca, 3 fragmentos y el impreso de Montalvo.

5. Algunas varianes estructurales:

— titulación o nombre del FR

— índices iniciales y sumarios de las leyes

- destinatarios del FR

- explicit o colofón

— las dos formulaciones de la ley 1.5.1: sobre dar galardón a los servidores y a Dios, en versiones breve y extensa.

\footnotetext{
${ }^{48}$ Las Leyes de Alfonso X. II. El Fuero Real, Avila, 1988 (edición y análisis crítico, MD, con la colaboración de José Manuel Ruiz Asencio, estudio paleográfico, y César Hernández Alonso, estudio lingüístico). Durante la preparación del trabajo había presentado una ponencia titulada «Los comienzos de la Recepción del Derecho Romano en España y el Fuero Real» (Diritto comune e diritti locali nella Storia dell'Europa, Milano, 1980, pp. 251-262).
} 
— la ley 1.5.3: regulación extensa sobre el pago de diezmos a la Iglesia, de carácter adventicio.

- las iglesias juraderas: la burgalesa de Santa Gadea; sus variantes, dudosas.

- la ley 4.8.3: en ocasiones desplazada a 4.9.3; trata de los que yacieran con mujeres de parientes directos.

- el título de los rieptos: la mayor de todo el libro, por afectar a un título completo. Pieza adventicia, posterior a la redacción del FR.

6. Datación del FR: anterior a 1255, altamente probable que sea anterior a 1252 (durante el período en que gestionó el Reino en ausencia de su padre, combatiendo en Andalucía).

7. Autoría del FR: el rey como promotor; sólo identificable como autor material el maestro Jacobo de las Leyes.

8. El FR otorgado a los concejos como derecho local (la expansión territorial...).

9. Normas de transcripción

\subsection{Mari Luz Alonso Martín}

La principal aportación de esta autora al tema que nos ocupa es su participación en la elaboración del Catálogo foral que ya hemos comentado, sin embargo, el trabajo de GG sobre los fueros de Toledo ha determinado en buena medida los desvelos investigadores de esta autora, especializada, en cualquier caso, en el ámbito del derecho privado. Así, en un mismo número del Anuario, el de 1978, llegó a publicar cuatro trabajos distintos, tres de ellos relacionados con el derecho toledano: uno de ellos sobre el ordenamiento jurídico vivido en la capital visigoda desde Alfonso VI hasta el final de la Edad Media, ${ }^{49}$ otro sobre la dote en los documentos toledanos (siglos XII-XV) ${ }^{50} \mathrm{y}$ un tercero relativo al modo toledano de revisión de la sentencia. ${ }^{51}$ El cuarto trabajo versaba sobre el derecho de troncalidad. ${ }^{52}$

49 «La perduración del Fuero Juzgo y el derecho de los castellanos de Toledo», AHDE, XLVIII, 1978, pp. 335-378. Introducción: al hilo del artículo de GG, se cuestiona por el derecho realmente vivido en Toledo desde Alfonso VI hasta fin de la Edad Media. El derecho de los castellanos: jurisdicción, el alcalde de los castellanos y de los mozárabes: hasta fines del Medievo se mantiene la dualidad de alcaldes. Contratos según el fuero de castellanos: preponderancia del Liber para todos los toledanos. Fuero de los castellanos o fuero castellano: los menos documentos privados son redactados de acuerdo con el fuero de castellanos. No sabe la autora cuál sea este derecho de castellanos. Entiende, no obstante, que hubo una redacción ya en el siglo XIV, cercano en su contenido al Fuero Viejo, de fondo consuetudinario. Documentos.

${ }^{50}$ «La dote en los documentos toledanos de los siglos XII-XV», Ibidem, pp. 379-456. La perduración del Liber en materia de dote. Dote según fuero, uso y costumbre de Toledo: fusión de dos sistemas dotales. Dote según Fuero Juzgo 3.1.6. Régimen económico de gananciales. 17 documentos.

${ }^{51}$ «La revisión de la sentencia según costumbre de Toledo», Ibidem, pp. 543-547. Especificidad toledana documentada en un proceso civil de 1384-1385, en el que el reo apela de la sentencia dictada por el alcalde ante los demás alcaldes de la ciudad, antes de recurrir a la instancia regia.

52 «Un caso de supervivencia de los fueros locales en el siglo XVIII. El derecho de troncalidad a fuero de Sepúlveda en Castilla la Nueva a través de un expediente del Consejo de Castilla», Ibidem, pp. 593614. Glosa del expediente 1.659, $\mathrm{n}^{\circ} 3$, de Consejos (AHN), en el que se solicitó por parte de Jadraque y otros pueblos de Guadalajara al Rey que declarase el alcance y contenido del Fuero de Sepúlveda en lo relativo al derecho de troncalidad, que decían que era el usado habitualmente en la zona. Incluye en apéndice los documentos del expediente. 
A1 Fuero de los castellanos volvió a dedicar dos trabajos más. ${ }^{53}$ Siguiendo la estela de los documentos mozárabes publicados por González Palencia, AM se ocupó tanto de la compraventa ${ }^{54}$ como de la sucesión mortis causa,${ }^{55}$ sin olvidarnos del mencionado trabajo sobre la dote. Precisamente al tema de la dote en los fueros medievales en el tiempo de la Recepción AM dedicó su intervención en el Convegno di Varenna. ${ }^{56}$

\subsection{Ana María Barrero García}

Como puede apreciarse de lo dicho hasta ahora, ninguno de los discípulos de García-Gallo continuó la senda de su maestro en el estudio histórico-crítico de los fueros medievales: de modo parecido a lo relatado en la parábola evangélica de la cizaña y el trigo, unos iniciaron el camino, pero lo abandonaron luego, para usar los fueros como fuente de datos para realizar sus trabajos sectoriales, otros decidieron patear el campo y los archivos a fin de poner negro sobre blanco los fueros ciertos o imaginados en el área castellana, paseándose por los contornos del método enarbolado por su maestro y algunos otros, por fin, escogieron sus trabajos en las temáticas del gusto de GG, pero sin incidir en la mencionada metodología.

\footnotetext{
${ }^{53}$ «Nuevos datos sobre el Fuero o Libro castellano», AHDE, LIII, 1983, pp. 424-455. Introducción: estudio de un códice donde se contiene parte de un texto de derecho castellano, basado en el Fuero Juzgo, conocido a través de las glosas a Fuero Real y el mismo Fuero Juzgo que hacen referencia al desconocido texto; proveniente de la segunda mitad del siglo XIV y principios del XV. En Toledo existía en esos momentos otro similar conocido como Leyes de Nuño González, que probablemente sea el libro castellano o fuero de los castellanos. Descripción del Códice BN-17.809. Fuentes utilizadas. El Fuero o Libro castellano. Conclusiones. Dos apéndices y una tabla de concordancias.

«Observaciones sobre el Fuero de los castellanos y las leyes de Nuño González», AHDE, LV, 1985, pp. 773-782. Versa sobre un códice (BN, ms. 10.344), conteniendo una copia moderna del Fuero Juzgo, con las concordancias de las denominadas Leyes de Nuño González, que alcanzan el número de 23 concordancias, sin contar los paralelismos con otros textos legislados. Ello le permite ofrecer dos cuadros de concordancias, entre dichas Leyes de Nuño González y el Fuero Juzgo y entre las Leyes y el Fuero de los castellanos.

${ }^{54}$ «La compraventa en los documentos toledanos de los siglos XII-XV», AHDE, XLIX, 1979, pp. 455517. La perduración del Fuero Juzgo en el contrato de compraventa. Compraventa a fuero de Toledo con marjadraque. Laesio enormis: prohibida en el Liber, es retomada en el Fuero Real. La continuidad de la fórmula notarial musulmana. 15 documentos.

${ }^{55}$ «La sucesión mortis causa en los documentos toledanos de los siglos XII-XV», AHDE, L, 1980, pp. 941-970. Analiza las pervivencias del derecho visigodo en los testamentos, junto a elementos de otras procedencias, como la institución de los 5 sueldos, que considera de patrón franco. 2 documentos.

${ }^{56}$ «La dote en el derecho local y en el derecho territorial castellano bajo la Recepción», Diritto Comune e diritti locali nella Storia dell'Europa. Atti del Convegno di Varenna, Milano, 1980, pp. 285-302. Tras recalcar la falta de trabajos sobre el derecho privado castellano en la época de la Recepción, se centra en el régimen económico del matrimonio. Distingue varios tipos de dotes: castellana, la de Galicia León y Portugal, la toledana - estas dos de raigambre visigoda - y la dote en los fueros tardíos de Castilla y León. A partir de Alfonso X se extiende la regulación del Fuero Juzgo, en su difusión como fuero municipal, el Fuero Real, las Partidas y las leyes de Toro.
} 
Puede decirse que tan sólo Ana Barrero ha seguido, con una linealidad y una reiteración encomiables la senda de García-Gallo. De hecho, comentar los trabajos sobre fueros medievales de esta autora resulta una labor grata, por cuanto, prescindiendo de los datos concretos de cada fuero o familia, la mayoría de sus trabajos obedecen a un mismo patrón, tanto en lo que se refiere al método de trabajo como al modo expositivo de sus conclusiones. Todo ello, como decimos, siguiendo a pie juntillas lo previsto por su maestro.

\subsubsection{Trabajos sobre fueros castellanos y aragoneses}

La andadura de esta licenciada en Historia en el ámbito del derecho medieval se produce ya en 1971, cuando defiende en Salamanca, donde había cursado sus estudios previos, una tesis, cuyo ponente fue Miguel Artola, lo que cuesta creer teniendo en cuenta la temática elegida. García-Gallo contaba entre los miembros del tribunal, pero no creemos errar si le atribuimos la dirección del trabajo. ${ }^{57}$

De acuerdo con el resumen publicado a poco de su lectura, este sería el contenido de esta tesis doctoral:

Estudio de los fueros concedidos a Sahagún, así como de aquellos otros lugares que recibieron esos mismos fueros, empleando el método histórico-crítico, lo que le permite: establecer las fechas, autenticidad y relaciones entre los textos; reconstruir el proceso de elaboración de los mismos y realizar un estudio de las instituciones que aparecen en los textos, señalando sus procedencias.

— Los fueros de la familia de Sahagún: los de Alfonso VI en 1085, Alfonso VII en 1152 y Alfonso X en 1255, además del arancel de portazgo y dos crónicas contemporáneas.

- Las concesiones del fuero de Sahagún a otros lugares: Oporto, San Martín de Madrid y San Frutos, Silos, Oviedo y Avilés, Allariz, Ribadavia, Quintanilla, Santander y, de nuevo, Silos. Estos, a su vez, se extienden a otros lugares.

- Crítica diplomática: necesaria, al conservarse los textos en copias tardías o defectuosas.

- El cotejo de los textos: la crítica textual y el examen de la tabla de concordancias permiten establecer la existencia de diversas redacciones, unas que se han conservado y otras perdidas, que se pueden reconstruir conjeturalmente:

1. las efectuadas en Sahagún (13 redacciones)

2. las efectuadas fuera de esa villa (8 redacciones)

- Stemma de redacciones.

Tan sólo un año tardaría en ver la luz en el Anuario la versión completa del trabajo: ${ }^{58}$

Introducción: escaso conocimiento de la problemática hasta esa época; bibliografía insuficiente. Estado de la cuestión.

\footnotetext{
${ }^{57}$ Fueros y cartas pueblas castellano-leoneses: fueros de tierra de León (Los Fueros de Sahagún) [resumen de tesis doctoral. Facultad de Filosofia y Letras. Universidad de Salamanca], Madrid, 1971. Tesis leída en 24/04/1971 (ponente, Miguel Artola, otros miembros del tribunal, AGG, Francisco Tomás y Valiente, José Luis Martín y Manuel Fernández Alvarez).

${ }^{58}$ «Los Fueros de Sahagún», AHDE, XLII, 1972, pp. 385-597.
} 
$\left.1^{\circ}\right)$ Las fuentes de conocimiento:

a) descripción y crítica de los textos:

- los fueros de la villa de Sahagún: las cartas de fuero conservadas (Alfonso VI en 1085, Alfonso VII en 1152 y Alfonso X en 1255). Otros privilegios. Descripción de todos ellos. Los dos primeros fueros presentan ciertas anomalías. También se menciona el arancel de portazgo del siglo XII y los datos cronísticos.

- las concesiones de los fueros de Sahagún a otros lugares: Oporto, San Martín de Madrid, San Frutos, Silos, Oviedo, Avilés, Allariz, Ribadavia, Quintanilla, Santander y Silos, otra vez; desde algunos de éstos se extiende a otros lugares, como el de Santander a Santillana. Necesidad de una crítica rigurosa por haber llegado en copias tardías o defectuosas.

- conclusiones: estos fueros tuvieron más importancia de la que cabía esperar de una villa surgida a la vera de un monasterio; se difunde en dos medios, el abacial y las villas señoriales o de realengo, en el ámbito costero; no eran tan desfavorables cuando fueron pedidos por lugares de realengo; el difundirse en lugares costeros un fuero sin contenido apropiado para ello indica que se trataba de fueros privilegiados.

b) el cotejo de los textos:

- criterios con que se ha realizado

- tabla de concordancias

- conclusiones: inexistencia de un texto único, sino que hubo varios textos que, usados aisladamente o reuniéndose en un determinado momento, dan lugar a los documentos hoy conservados.

De las redacciones usadas unas se han perdido y otras conservado, si bien se puede hacer una reconstrucción conjetural de acuerdo con las coincidencias entre los distintos textos. Stemma.

$2^{\circ}$ ) Historia de los fueros de Sahagún

a) la fundación de la villa y sus primeros fueros

— la formación de la villa: artesanos y mercaderes ultrapirenaicos.

- concesión del fuero

- ¿su extensión a Oviedo, Avilés y Silos?

- el contenido del fuero

- nuevos fueros o privilegios de Sahagún

b) revisión del fuero por el abad

— don Diego y la carta de 1085: para afianzar el poder del abad frente a los burgueses, aquél no duda en falsificar esa carta, usando modelos auténticos.

- su contenido

c) los burgueses de Sahagún defienden su fuero contra el abad y su fuero

- la actitud de los burgueses ante la situación política: a la muerte de Alfonso VI, en tiempos de doña Urraca y el Batallador, tomando partido por éste.

- el resultado de la revuelta: el fuero oficial y el fuero del concejo: repulsa de la carta de 1085 y vuelta al texto primitivo, favorable al concejo. El levantamiento supuso el triunfo de las aspiraciones de los burgueses. Deja de ser un fuero señorial de corte francés, el que don Diego había intentado imponer, para ser un fuero burgués, un privilegio excepcional, digno de ser reclamado para ser usado en otras ciudades.

d) la expansión del fuero de Sahagún en el siglo XII (el del concejo, el del monasterio quedará olvidado en su archivo)

- caracteres generales

— la expansión del fuero oficial: Oporto, San Martín de Madrid, etc.

- la expansión del fuero del concejo: elaborado por el concejo, se extiende desde la segunda mitad del siglo XII; extendido a concejos de realengo (Oviedo y Avilés, Allariz y Ribadavia) y abaciales (Sahagún de 1152 y Silos de 1209, Santander y Santillana).

e) el fin del fuero de Sahagún 
- el fuero de Sahagún de 1255: Alfonso X intenta poner fin a las discordias entre abad y concejo, mediante la concesión de fueros. Estas discordias provenían del deseo de los burgueses de emanciparse del señorío abacial, y se rastrean en los reinados de Alfonso IX, Fernando III y Alfonso X. Se mantiene en el nuevo fuero el señorío del abad, al que se atribuye una acción supervisora, así como los tributos no reales.

- la concesión del FR y el FJ: también se incluye en el fuero la remisión al FR, que acaba siendo desplazado por el Liber.

Los problemas entre el concejo y el monasterio continuarán hasta su definitiva resolución por los Reyes Católicos.

Apéndices: plano de difusión y tablas (pp. 530-597)

Con este trabajo GG cumplía su anhelo de dejar estudiados los fueros más notables del área noroccidental de la Península (León, Benavente, Llanes, Sahagún). Tocaba ahora seguir con el estudio, nuevamente intentado ahora, de la familia del Fuero de Cuenca. La primera aproximación de BG al tema se produjo con ocasión de la aparición de El fuero latino de Teruel, de Jaime Caruana; El fuero de Béjar de Juan Gutiérrez Cuadrado y la tesis doctoral de Alberto García Ulecia. De ellos se ocupó, dentro de la sección Miscelánea, del Anuario de 1976. ${ }^{59}$

Debido a las carencias de las ediciones de fueros, ajenas a los intereses del historiador del Derecho, BG insiste en la importancia de los aspectos externos en la presentación de un texto, así como en los trabajos auxiliares para su comprensión. Encuentra muy estimable y de uso obligado el aparato terminológico de Gutiérrez Cuadrado y se apresta a responder a la invitación hecha por Caruana sobre el tema de la prelación entre los textos de Sepúlveda, Cuenca y Teruel.

Para ello parte de la hipótesis «de la formación progresiva de sus textos [del Fuero de Cuenca] a partir de un derecho escrito y consuetudinario anterior al momento de las concesiones a localidades concretas de que tenemos noticia y su reelaboración en ellas hasta quedar definitivamente fijados (momentos entre los que media un amplio espacio temporal)». Planteamiento este desarrollado por GG, defendiendo la existencia de redacciones privadas que influyen sobre textos de fueros conocidos.

Aboga por abordar el estudio de la familia del FC desde esa perspectiva:

- esta evolución de los fueros de la Extremadura no es un hecho excepcional.

- ausencia de cláusulas diplomáticas que vinculen los textos a la cancillería real.

- el anacronismo que supone situar la concesión del FC a la época final del siglo XII, cuando se suelen conceder privilegios y fueros breves.

- la influencia del Derecho Romano en numerosos preceptos.

- la escasa difusión del FC al poco de su supuesta concesión.

- la existencia de un texto formulario anterior a las redacciones conocidas, usado sistemáticamente por Fernando III en el Reino de Jaén.

GG señala la necesidad de realizar un stemma de los fueros derivados de FC; su ausencia crea inseguridades y errores, como algunos que BG señala en el trabajo de

\footnotetext{
${ }^{59}$ «La familia de Fueros de Cuenca», AHDE, XLVI, 1976, pp. 713-726.
} 
García Ulecia. Los estudios filológicos son útiles, pero defiende el estudio institucional, mediante la reconstrucción del proceso de compilación: cotejo y crítica textual de todos los fueros.

Transcurridos sólo seis años, luego de haber editado un extenso trabajo sobre el Fuero de Teruel, BG volvió a incidir sobre la problemática en cuestión, de acuerdo con los siguientes puntos: ${ }^{60}$

$1^{\circ}$ ) Estado actual de la investigación: falta de una revisión del tema, desde lo asentado por Ureña en su edición.

$2^{\circ}$ ) Análisis del FC: el texto no procede de la cancillería de Alfonso VIII; una parte del mismo procede de una época anterior a este monarca. Sobre el texto actuaría un jurista experto tanto en derecho vernáculo como en Romano. Tiene una extensión y contenido impropio de fines del siglo XII, por lo que sería anacrónico situarlo en esa época. No defendible que los textos derivados del FC provengan del texto que se considera inicial. Habría que posponer a mediados del siglo XIII su redacción.

$3^{\circ}$ ) La relación de FC y FT: no procedería el uno del otro, sino que ambos derivan de un modelo común.

$\left.4^{\circ}\right)$ La formación del FC:

- la naturaleza del FC: ha sido redactado en diferentes momentos; algunas normas aluden a referencias geográficas no ubicables en Cuenca; etc. Se trata de una recopilación de textos de diferentes orígenes y tiempos, retocados por juristas. Se trataría, pues, de identificar las redacciones, reconstruir su ubicación espacial y temporal, todo ello mediante el cotejo de los textos disponibles. Labor ésta ímproba, que de momento sólo permite avances parciales.

Cabe reconstruir en líneas generales el proceso de formación y desarrollo de la Extremadura así:

- las primeras redacciones del Derecho de la Extremadura: en la Extremadura se aprecia un derecho muy homogéneo, basado en los privilegios recibidos durante su repoblación. Después las lagunas existentes se van rellenando con nuevos privilegios, fazañas o sentencias judiciales, ordenanzas municipales, notas de jueces o prácticos en derecho, costumbres locales. Por distintas vías y en diferentes momentos todo ese material se va incorporando al acervo local, que los concejos intentan que sea aprobado por los monarcas. Esto anima a los municipios a redactar estas refundiciones, a fin de obtener la validación real.

— la formación de los «Libros»: a partir de esos textos refundidos los juristas locales amplían, aclaran y actualizan sus libros, ordenándolos y sistematizándolos, llegándose a la creación de un Formulario.

Es decir, una vez tras otra todos los autores que venimos glosando hacen hincapié en la necesidad de proceder al estudio de la familia conquense, pero una cosa era proclamar esa necesidad y otra muy distinta cumplimentarla. En cualquier caso, BG sí aportó su grano de arena para avanzar en esta investigación, enfrentándose al no fácil problema del fuero de Teruel. ${ }^{61}$

Problemas que plantea: cómo se formó, cuáles fueron sus fuentes de inspiración, qué elementos lo componían, quiénes intervinieron en su elaboración.

${ }^{60}$ «El proceso de formación del Fuero de Cuenca», Anuario de Estudios Medievales, XII, 1982, pp. 41-58.

${ }^{61}$ El Fuero de Teruel. Su historia, proceso de formación y reconstrucción crítica de sus fuentes, Teruel, 1979. 
$\left.1^{\circ}\right)$ El FT en el proceso de formación del Derecho aragonés:

- del Derecho pirenaico al del Aragón Central

- los orígenes del Derecho de la Extremadura

- el FT como culminación del Derecho de la Extremadura aragonesa

- la difusión del FT

$2^{\circ}$ ) Estudio crítico del fuero latino de Teruel y de su relación textual con los fueros de la Extremadura aragonesa:

— estado actual de la investigación: los estudios sobre el FT y nuevos planteamientos.

— el FT: manuscritos y ediciones; análisis del texto latino: a) análisis diplomático. b) análisis del contenido: repeticiones, tipos de cláusulas —cláusulas normativas y glosas—, interpolaciones y adiciones; y fuentes aragonesas del FT: a) fuentes de conocimiento: fueros de Calatayud, Daroca y Alfambra; b) tablas de concordancias entre esos tres fueros, el apéndice y los fueros de Teruel y Cuenca: criterios de elaboración, tabla y conclusiones (respecto a los tres primeros fueros, responden a modelos diferentes); c) resultados del cotejo textual: naturaleza de las concordancias, estudio comparativo de los textos y conclusiones (existencia de varias redacciones; en cuanto a la prioridad entre FT y FC, la autora se muestra partidaria de rechazar una relación inmediata entre ambos y defiende la existencia de un modelo común, hoy perdido, común para ambos, lo que explicaría los paralelismos existentes); y d) Stemma.

$\left.3^{\circ}\right)$ Reconstrucción hipotética de los textos aragoneses que integran el FT: reconstrucción del fuero primitivo, reconstrucción de los textos C, X1, D y X2, tabla de concordancias entre los textos de Teruel y Cuenca.

Tras esa atrevida deconstrucción y reconstrucción del texto turolense, BG dejó pasar tres lustros para volver a reflexionar sobre el mismo, haciéndolo en términos similares a los usados anteriormente. ${ }^{62}$ Para ello expuso los ocho puntos siguientes:

- El FT conservado en varios códices medievales, en lengua latina o en romance, incluyendo otros dos adecuados a las circunstancias de Albarracín y Castiel. Se trata de textos que plantean problemas, que han sido tratados a lo largo del siglo XX por especialistas de distinta formación.

- Estado de la cuestión de las ediciones habidas; existe correspondencia entre el nivel alcanzado por las ediciones del FT y el de los estudios dedicados a éste.

- Las introducciones a los textos editados no han tenido el menor asomo de sentido crítico respecto al otorgante o la fecha o circunstanciuas de la concesión. Esto ha impedido el avance de la investigación.

— Revulsivo al debate que supuso la obra de Ureña, defendiendo la prioridad de Cuenca sobre Teruel; más tarde Caruana ha pedido se aclare definitivamente la cuestión, que viene lastrada por apriorismos localistas y defectos de planteamiento.

- GG había planteado en los años 50 la necesidad de entender el derecho de la Extremadura como algo homogéneo, obra de redactores privados, cuyas obras hoy perdidas sirvieron para formar los fueros conocidos.

- A mediados de los 70 surgen la obra de Lalinde (Los Fueros de Aragón), que incardina el derecho de la Extremadura aragonesa dentro de la evolución de la foralidad de ese Reino, y la de BG, deudora de los planteamientos de GG. La crítica textual no permite, en su opinión, establecer una relación textual inmediata entre FC y FT.

- Línea favorecida por el desarrollo de los estudios del medievalismo aragonés (Lacarra, Ubieto, Ledesma, Gargallo), así como del profesor Lalinde.

${ }^{62}$ «Los Fueros de Teruel y Albarracín (Apunte historiográfico)», Los Fueros de Teruel y Albarracín. Actas de las Jornadas de estudio celebradas en Teruel y Albarracin, Teruel, 2000, pp. 269-279. 
— La obra de Gargallo sobre el concejo turolense ha venido a confirmar y ampliar lo apuntado por BG, la cual opina que queda mucho por hacer en cuanto a la edición de fueros (Calatayud, Alfambra, Albarracín o Castiel) y en lo relativo a su estudio.

Otros dos trabajos sobre fueros del área occidental dedicó Ana Barrero en distintos momentos de su trayectoria profesional: uno dedicado al fuero breve de Salamanca, en 1980, y otro a varios forais portugueses, en 2007. Por lo que se refiere al primero, se trataba de una labor detectivesca para intentar reconstruir el contenido del texto a partir de las concesiones del mismo a varias localidades lusas: ${ }^{63}$

$\left.1^{\circ}\right)$ Introducción: como en otros lugares de la Extremadura, aquí se recibió una carta foral, de cuya existencia se sabe por haberse conservado algunos preceptos en la normativa posterior; ésta fue fruto de la labor compiladora del concejo, incluyendo sus fueros y costumbres. Se supone la existencia de un fuero primigenio dado por Raimundo de Borgoña, luego extendido ampliamente por Portugal (26 localidades, en la Beira Baixa).

Se intenta reconstruir su contenido a base de la comparación entre los textos existentes en ambos Reinos.

$\left.2^{\circ}\right)$ Las concesiones del Fuero de Salamanca en Portugal:

- las fuentes de conocimiento: sólo a partir de 6 fueros.

- tabla de concordancias

- estudio comparativo de los textos (el Fuero de Numâo; preceptos sin paralelo en el fuero de Numâo; y preceptos propios de cada fuero).

$3^{\circ}$ ) Conclusiones: existieron varias redacciones del FS, unas conservadas, otras no, siendo posible reconstruirlas a partir de los otros fueros. Stemma.

$\left.4^{\circ}\right)$ El Fuero breve y el fuero del concejo: se desprende de la reconstrucción realizada que los redactores del FS no tuvieron en cuenta en absoluto el fuero breve; en éste se había concedido el derecho tradicional castellano: concesión de infanzonía a los caballeros villanos en juicios y juramentos, la obligación de acudir al fonsado el tercio de los mismos, la entrega del quinto del botín o la penalización por el abandono del cónyuge.

Muy original es el planteamiento desarrollado por BG a la hora de enfrentarse con los forales de Coímbra, Lisboa y Santarem. ${ }^{64}$

$\left.1^{\circ}\right)$ Planteamiento: se trata de tres textos muy parecidos, concedidos simultáneamente por Alfonso I Enríquez, coincidiendo con el mismo mes de mayo de 1179, en que Alejandro III acogía el Reino de Portugal bajo su protección. Textos confirmados en 1217 por Alfonso II.

$\left.2^{\circ}\right)$ Los fueros de Coímbra, Lisboa y Santarem. Su análisis crítico:

- su crítica diplomática: presentan ciertas anomalías, tanto en los textos iniciales como en sus confirmaciones.

- su crítica interna: algunos aspectos sorprendentes en la formulación de sus disposiciones (confundir civitates y villae, utilizar indistintamente maravedí y sueldo, usar al tiempo términos institucionales latinos y romances, etc.).

- conclusiones: se trata de textos apócrifos, ajenos a la cancillería regia, adoptados por los vecinos, que obtuvieron su confirmación por Alfonso II en 1217-1218. Colección de nor-

63 «El Fuero breve de Salamanca. Sus redacciones», AHDE, L, 1980, pp. 439-468.

${ }^{64}$ «Orden jurídico e identidad política en los albores de la Recepción del Derecho Común (sobre los forais de Coimbra, Lisboa y Santarém)», Hispania, CCXXVII, 2007, pp. 827-848. 
mas forjada por un jurista formado en el Derecho Común, tomándolas del ámbito territorial de Coímbra.

$3^{\circ}$ ) Otra historia para estos Fueros: a pesar de todos los anacronismos, en opinión de BG, se trataba de fundamentar la exemptio imperii del nuevo Reino respecto al castellano-leonés, mediante el recurso al Rey fundador de Portugal. Muestran el arraigo social de las doctrinas del Derecho Común en lo relativo tanto al poder real como al valor de la norma escrita.

A la postre, el fuero que más atenciones recibiría de esta autora sería el de Logroño, del que ya se había ocupado también MD, como se ha visto antes. En tres ocasiones reflexionó BG sobre el texto logroñés. En la primera de ellas lo hizo a través de las redacciones utilizadas en territorio navarro. ${ }^{65}$

Planteamiento: tradicionalmente se ha pensado que estos textos representaban un subgrupo bien definido dentro de la familia del Fuero de Logroño, derivados directamente del fueron de Laguardia. Idea que BG desmonta con una mera lectura, a causa de su simplicidad.

Análisis diplomático de los documentos: detecta anomalías en prácticamente todos los textos conservados, que, aunque no proceden directamente de la cancillería real navarra, se inspiran en originales que sí lo eran.

Crítica textual: criterios utilizados, tabla de concordancias (Logroña, Laguardia, Vitoria, Antoñana, Arganzón), resultados de la tabla de concordancias - distingue los preceptos comunes con el Fuero de Logroño de aquellos que lo son entre los fueros navarro-alaveses, pero que no aparecen en Logroño-, cotejo textual (de los fueros-tipo, de los fueros que responden al modelo de Laguardia).

Conclusiones: todos los textos partirían de un modelo cercano al logroñés, del que se separarían dos ramas: $1^{\mathrm{a}}$ ) un texto desconocido del que derivarían el de Mendavia (1157), por un lado, y los de Viana y Aguilar, por otro; y $2^{\mathrm{a}}$ ) otro texto desconocido, del que se separaría una rama, que daría los fueros de Treviño y Arganzón, y otra, que partiendo de Laguardia (1164), se subdividiría en tres brazos: el de Antoñana y Bernedo (1182), el nuevo de Laguardia, con proyección sobre el de San Vicente de la Sonsierra, y, finalmente, el de Vitoria (1181) con sus variadas ramificaciones.

Apéndice: stemma de los fueros.

Dos años más tarde, con ocasión de la confección de una Historia de la capital de La Rioja, se encargaron a BG tres capítulos, todos relacionados con el fuero logroñés. En el primero de ellos se ocupaba de la historia del fuero, ${ }^{66} \mathrm{en}$ el segundo del estudio

${ }^{65}$ «Las redacciones navarras del Fuero de Logroño», Príncipe de Viana, CXCVI, 1992, pp. 409-428.

${ }^{66}$ «La historia del Fuero de Logroño», Historia de la ciudad de Logroño, Logroño, 1994, II, 171-178.

— La Rioja en la política foral de Alfonso VI

— La carta de población de Logroño: traslado de la capitalidad de Nájera a Logroño, con valor fronterizo frente a la taifa zaragozana; sin embargo, se le debieron dar privilegios para el asentamiento de francos, sin olvidar su carácter defensivo.

— De la «carta de población» a la «carta foral». Su proceso de formación: Alfonso VII confirma los privilegios de su abuelo, Alfonso VI, algo que la crítica diplomática echa abajo. Se trató de una reelaboración del fuero anterior, ampliándolo por mano privada. A pesar de todo, acabaría siendo sancionado, consolidándose y difundiéndose a otros lugares. En su difusión sirvió para aforar a villas defensivas, situadas en entornos señoriales, de modo que se atrajo a población libre que impulsara el 
crítico y edición ${ }^{67}$ y en el último sobre los textos relacionados con el mismo ${ }^{68}$ Cuatro años más tarde presentó una recapitulación de sus conclusiones en el mismo Congreso sobre dicho texto en que intervino también el padre MD. ${ }^{69}$

Planteamiento: comienza dudando de los otorgamientos de Alfonso VI y Alfonso VII, debido a los problemas que plantea el documento inicial conservado.

Estudio crítico de la carta foral

$1^{\circ}$ ) Estudio diplomático:

- la confirmación del fuero por Alfonso VII y la realización del traslado de la carta foral: no se corresponde con las características formales de la cancillería del Emperador. Tampoco coinciden las personas citadas. No parece redactado con documentos de la cancillería real a la vista, aunque sí puede documentar una actuación regia.

- la carta de población de Alfonso VI: la redacción del núcleo del documento podría proceder de su cancillería, aunque se advierten incoherencias.

- resultados de la crítica diplomática: no es traslado de una confirmación del fuero por Alfonso VII, aunque podría documentar una actuación regia; es obra del concejo, no del Rey. Respecto al propio fuero, no procede de la cancillería de Alfonso VI, si bien pudo tenerse presente al documento inicial, aunque intensamente alterado.

crecimiento económico, en Navarra, Vascongadas y Cantabria, además de La Rioja.

- El desarrollo del Fuero de Logroño: se dan sucesivas redacciones.

${ }^{67}$ «Estudio crítico y edición del Fuero de Logroño», Ibidem, pp. 179-194.

- Transmisión manuscrita y ediciones: necesidad de un tratamiento heurístico. Existen dos textos, uno logroñés y otro vitoriano, muy similares.

- Análisis de texto: estructura y composición; su crítica diplomática; la confirmación del fuero por Alfonso VII; la carta de población; conclusiones: dos, el fuero trasladado en 1148 no procede de la cancillería ni de sus aledaños, no obstante lo cual recoge documento de Alfonso VII dado con motivo de su repoblación; y su crítica interna: fruto de un proceso de refundición y reelaboración de textos anteriores hoy perdidos. Se trata de la integración del fuero original de población, por Alfonso VI, de un volumen de preceptos posteriores sobre exenciones de cargas señoriales, además de otros materiales de difícil individualización.

— Edición (texto del Fuero, pp. 187-193).

${ }^{68}$ «Los textos relacionados con el Fuero de Logroño», Ibidem, pp. 195-221.

— La difusión del Fuero de Logroño (cuadro): en zonas de soberanía distinta, pero homogéneas geográficamente y durante un tiempo prolongado. Dos momentos álgidos: los reinados de Alfonso VIII en Castilla y los navarros Sancho el Sabio y el Fuerte, por un lado, y, por otro, el siglo XIV, al tiempo de la repoblación de Vizcaya y Guipúzcoa.

- La familia textual (32 fueros): crítica diplomática y análisis de los fueros que la integran; los fueros castellanos (7); los fueros navarros (14); los fueros vizcaínos (9); y su relación textual: no son todos idénticos, mostrando la existencia de un complejo proceso redaccional.

- Establecimiento de las concordancias: criterios utilizados, tabla de concordancias, resultados.

- Crítica textual: preceptos que se dan entre los mismos; conclusiones: la difusión se produce a partir del texto confirmatorio atribuido a Alfonso VII; sólo los fueros de Santo Domingo, Frías y Bermeo se elaboraron a partir de texto conocido de Logroño; el resto se sirvió de recensiones del mismo, hoy no conservadas. Intenso proceso redaccional, que se muestra en distintos grupos de fueros, formando un stemma complicado.

${ }^{69}$ «Los enigmas del Fuero de Logroño», Actas de la reunión científica «El Fuero de Logroño y su época», Logroño, 1996, pp. 41-54. 
$2^{\circ}$ ) Crítica interna: no es cierta la aparente uniformidad de sus instituciones.

- reiteraciones normativas, diferencias redaccionales y criterios de ordenación.

- los diferentes textos constituvos de la carta foral: sería el resultado de una refundición de dos textos hoy desaparecidos.

- reconstrucción hipotética de su proceso de formación: sería un texto de formación tardía, fruto de un proceso sucesivo de yuxtaposición, refundición y reelaboración de materiales, sin que el análisis permita pronunciarse sobre fechas concretas.

Nuevamente en 2008 BG ha vuelto a tratar, siquiera sea parcialmente, del texto logroñés, a propósito de su estudio de los fueros de las Encartaciones de Vizcaya. ${ }^{70}$

$\left.1^{\circ}\right)$ Introducción: contemplación del problema desde la óptica positivista desde el siglo XVIII.

$\left.2^{\circ}\right)$ El proceso de formación de los textos forales: también las cartas de fuero suelen tener un origen compilatorio, algo de difícil asimilación por algunos.

$3^{\circ}$ ) La formación de los fueros vizcaínos:

a) las redacciones forales de las villas: sobre la base del texto logroñés.

- la carta foral de Logroño

— su recepción en las villas

— análisis diplomático de los textos forales:

1. los fueros de Valmaseda y Lanestosa: éste es una copia del otro; el fuero de Valmaseda no se corresponde con el supuesto fuero original dado por su señor; debió de ser redactado por el concejo para acoger los términos de un privilegio condal, en 1237.

2. el fuero de Bermeo

3. las cartas forales del siglo XIV: los textos de Lequeitio y Ondárroa muy cercanos. El de Portugalete sigue los textos de Bermeo y Bilbao. Siguen Bilbao, Durango y Ermua.

4. las versiones vizcaínas del estatuto riojano: gran fidelidad al modelo logroñés, en romance, con dos tradiciones textuales: una con sede en Valmaseda, anterior a la implantación en el Duranguesado. Otra, en el texto de Bermeo.

b) el derecho de la Tierra Llana: de origen consuetudinario y judicial, sin que falte el componente privilegiado. Entre mediados del siglo XIV y comienzos del XVI.

- el Fuero Viejo de las Encartaciones: no se trata de un texto unitario, aunque pueda proceder de una decisión de la Junta de Avellaneda.

- el Fuero de 1503: diplomáticamente impecable, suscita dudas su declarada dependencia respecto al fuero Viejo. Se habría reformado a partir de un texto más cercano.

Los cinco trabajos restantes dedicados por BG al estudio de distintos fueros o grupos de fueros se refieren a distintos lugares del antiguo Reino de Castilla y parecen responder a la oportunidad de presentar colaboraciones en distintos eventos científicos; así, se ocupó de los fueros de época condal y de los tres Alfonsos en el Homenaje que la UCM ofreció a su maestro en 1996. ${ }^{71}$

Planteamiento: desde principios del siglo XII se detecta un movimiento de redacción de textos de derecho local en el Reino de Castilla, especialmente, al norte del Duero, tanto en lugares se-

\footnotetext{
${ }^{70}$ «Los Fueros de las Encartaciones y otros fueros contemporáneos», Iure Vasconiae, V, 2008, pp. 103-152.

${ }^{71}$ «Notas sobre algunos fueros castellanos», Homenaje al profesor Alfonso García-Gallo, Madrid, 1996, tomo II, volumen 2, pp. 11-41.
} 
ñoriales como de realengo. Desde 1104, en que se concedió el fuero de Palenzuela, hasta 1220, en que el abad de Arlanza otorgó fueros a San Leonardo (Soria), se aprobaron en total 20 textos forales, incluidos los citados. Se supone que recogen el derecho tradicional castellano, formado en esa misma centuria y presentado como concesiones o confirmaciones de los condes Fernán González y García Fernández. Casi todos los textos conservados presentan anomalías en el ámbito diplomático, que hacen precisa una revisión crítica.

Análisis diplomático de los fueros: la presencia de anomalías y anacronismos no debe concluir con el desprecio del documento en cuestión, pues no quiere decir que se trate de un texto apócrifo.

$1^{\circ}$ ) las compilaciones forales: los fueros de Canales de la Sierra, Castrojeriz, Palenzuela y Lara.

$2^{\circ}$ ) Los documentos forales: a) los fueros de la época condal: los de Melgar de Suso y Salas de los Infantes; b) los fueros de Alfonso VII: Briviesca, Villadiego, Balbás, Atapuerca, Astudillo y Lerma; y c) los fueros de Alfonso VIII: Belbimbre, Pampliega, Villaverde-Mogina y San Juan de Cella.

Realiza el estudio diplomático y de contenido de cada texto, sin sacar conclusiones de ningún tipo.

Concretamente, sobre la política foral de Alfonso VI se había ocupado en 1987 con ocasión de un Congresos de estudios mozárabes. ${ }^{72}$

$1^{\circ}$ ) Planteamiento: ¿existió una política foral — que no legislativa- en la actividad política de Alfonso VI? Se constata la presencia de 26 fueros concedidos por este monarca.

$2^{\circ}$ ) Los fueros otorgados por Alfonso VI:

- privilegios de confirmación: los fueros de Nájera, Sepúlveda y Santarem; la confirmación de los fueros de Palenzuela y Castrojeriz.

- fueros concedidos a los lugares del Camino de Santiago: el fuero de Sahagún, las concesiones de Alfonso VI a Burgos, el fuero de Logroño, el fuero de Miranda de Ebro y el fuero de Lugo.

- fueros otorgados a lugares de Extremadura: fueros de Segovia, Avila y Salamanca; y fuero de Medinaceli.

$\left.3^{\circ}\right)$ La perduración de la obra de Alfonso VI: la difusión de los fueros de Sahagún y Logroño y la de los fueros de Extremadura.

$\left.4^{\circ}\right)$ Conclusiones: tras una primera etapa de consolidación en el trono, el monarca se dispone a favorecer la repoblación del territorio mediante la concesión de fueros, tanto en la frontera (la Extremadura) como en la retaguardia (el Camino de Santiago), consolidando los fueros anteriores que consideró de interés. Alfonso VII, Fernando II y Alfonso VIII tendrían la oportunidad de continuar su labor. La promoción de la vida urbana en todo el Reino debe mucho al conquistador de Toledo.

También su estudio del fuero de Carmona fue redactado como una ponencia presentada en el Congreso de historia de esa localidad sevillana. ${ }^{73}$

\footnotetext{
72 «La política foral de Alfonso VI», Estudios sobre Alfonso VI y la reconquista de Toledo. Actas del II Congreso Internacional de Estudios Mozárabes, Toledo, 1987, I, pp. 115-156.

${ }^{73}$ «El Fuero de Carmona», Archivo Hispalense, CCXLIII-CCXLV, 1997, pp. 387-414. En Actas del I Congreso de Historia de Carmona. Edad Media. Congreso conmemorativo del 750 aniversario de la conquista de la ciudad de Carmona por Fernando III. 1247, celebrado en Carmona, 22-25 de septiembre de 1997.
} 
$\left.1^{\circ}\right)$ Planteamiento: publicado en las Memorias de De Manuel, aún no se habían planteado en el momento del trabajo las incógnitas que presentaba.

$2^{\circ}$ ) Fernando III y el derecho del Reino: deseoso de reformar el ordenamiento jurídico, mediante varios expedientes, tales como confirmar las recopilaciones según promesa de Alfonso VIII; puesta por escrito del ordenamiento consuetudinario de pueblos de la Extremadura; mediación en los conflictos sobre el derecho vigente, ordenando pesquisas; y actualizar aspectos de fueros, ampliándolos. No se pretende crear una normativa de carácter general, sino que se extiende tanto el Fuero de Cuenca como el Liber por zonas. Este se concede a Córdoba o Sevilla, pero la concesión a Carmona no hace ninguna referencia local.

$\left.3^{\circ}\right)$ El Fuero de Carmona, su estudio crítico:

— análisis diplomático: sólo se conserva un traslado en pergamino de 1396, que es una copia simple, realizada por el concejo para preservar su fuero original, en papel. No hay ningún otro texto con que compararlo. Se trata de una copia del fuero latino de Córdoba, con el añadido de las rúbricas de las normas. Contiene algún anacronismo y anomalía.

— análisis interno: se trata de una versión en romance del fuero latino de Córdoba, en el que faltan dos artículos.

- conclusiones: copia sacada teniendo delante el original de Fernando III o copia fidedigna del mismo. El contenido procede del fuero latino cordobés a través de un modelo común a Carmona y Fuero latino de Córdoba.

- su proceso de formación: presenta elementos sospechosos, como la presencia de varios actores (el rey con la reina, la reina como señora de Carmona y el señor de Carmona). Es un texto elaborado por el concejo imitando la diplomática real; la concesión real habría sido una remisión genérica al Fuero cordobés. Ahora buscaban la confirmación regia de su privilegio, que resulta fallida. Alfonso X les concede el fuero de Sevilla y determina que las alzadas de Carmona se dirijan a los alcaldes sevillanos.

Resultado de una conferencia celebrada con el patrocinio del ayuntamiento capitalino sería su librito sobre el contexto jurídico del fuero madrileño, editado en $2003 .{ }^{74}$

$\left.1^{\circ}\right)$ Introducción: dificultad para aproximarse a la génesis y contenido del texto.

$2^{\circ}$ ) El derecho de la villa de Madrid antes de la formación de su libro de fuero: escasez de noticias; cabe pensar que fue repoblado con castellanos, que aportarían su arraigado, pero no escrito, derecho.

$\left.3^{\circ}\right)$ El Fuero de Madrid:

a) el códice del Fuero de Madrid: un único códice de comienzos del siglo XIII, sin carácter unitario y no conservado en su totalidad. Falta el segundo cuadernillo de los cuatro que lo formaban, con algunos añadidos al final. Sin fórmula de aprobación oficial; sólo se menciona la fecha de 1202 .

b) génesis y contenido del Fuero:

— análisis crítico de la «carta de Fuero»: formada por 109 capítulos; se trata de una compilación de elementos diversos. Aquí BG analiza el contenido penal/procesal, en especial, así como la base económica del mismo.

- la «carta de Otorgamento»: fruto del acuerdo entre el Rey y el concejo; adopta caracteres propios de los privilegios reales, pero no cumple sus normales exigencias.

— las avenencias del concejo: 7 disposiciones del concejo madrileño en distintos momentos.

- el proceso de formación: respecto a la carta inicial oscila entre atribuirla a Alfonso VI, contemporáneamente a la conquista de Toledo, o a Alfonso VIII; en este caso, rezaría la fecha

\footnotetext{
${ }^{74}$ El contexto jurídico del Fuero de Madrid, Madrid, 2003.
} 
de 1202, si bien esto no implicaría que todo el texto fuera de esa época. Se formaría a partir de un texto foráneo de vida extensa, de la práctica judicial local y de instrumentos concejiles, como la pesquisa de 1194, refundiéndose los materiales.

Menos compleja es la gestación de la carta de Fuero, posterior a la de Otorgamento, pues el concejo actúa con conciencia de su capacidad para actuar, con el beneplácito regio, vuelto en 1212 de la hueste sobre Baeza. Probablemente en época de Fernando III se añadió la parte del Otorgamento al Fuero, añadiéndose unas hojas al códice, quedando integradas por su valor simbólico.

Finalmente, a despecho del título concreto de su aportación, BG ha aportado su aquilatado método al estudio del fuero de Jaca, de nuevo, dentro de los estudios reunidos sobre este texto. ${ }^{75}$

$\left.1^{\circ}\right)$ Planteamiento: ¿procede el derecho jacetano de una concesión de Sancho Ramírez? Esto es lo aceptado, pero BG lo pone en duda.

$2^{\circ}$ ) Los documentos forales de Jaca: textos reunidos en el Libro de la Cadena (1398):

a) el fuero de Sancho Ramírez:

— tradición manuscrita: han pervivido dos ejemplares, un pseudo-original pergamino del siglo XII y la copia en el Libro de la Cadena.

- crítica diplomática: presencia de anomalías, que indican la existencia de elementos de distinta procedencia.

b) la confirmación de Ramiro II: dos copias conservadas de la misma en el Libro de la Cadena, con diferencias muy notorias. Presenta anomalías, si bien se trata de un texto muy cercano al verdaderamente salido de la cancillería real.

c) la concesión de Alfonso II: ¿es cierto, como afirma el rey en el preámbulo, que de Castilla y Navarra iban a Jaca a inspirarse en su derecho? Sólo conservado en una copia del Libro de la Cadena. Ha sufrido sensibles modificaciones, siendo de compleja composición. Se trata de un documento reelaborado sobre una base documental fidedigna.

d) conclusiones derivadas de la crítica diplomática: los preámbulos muestran una reelaboración unitaria, buscando ensalzar a la ciudad y su famoso derecho; datable en la segunda década del siglo XIII.

$3^{\circ}$ ) La difusión del Fuero de Jaca

— los testimonios documentales: en Navarra, por iniciativa regia, en relación con la ruta jacobea.

— análisis comparativo de los textos relacionados con FJ

- fijación de las concordancias existentes entre los textos

— resultados de la tabla de concordancias

- análisis textual de las concordancias

$4^{\circ}$ ) El proceso de formación del derecho jacetano: panorama dinámico; Sancho Ramírez reconoce los asentamientos habidos en Jaca, Sangüesa y Estella, dándoles, además, privilegios. En una segunda fase, se produce una fijación por escrito de normas fruto de la convivencia de personas en un lugar con características especiales, esto es, en Jaca. Esto da lugar a varias redacciones, que bajo Ramiro el Monje alcanzan su consagración definitiva.

\subsubsection{Trabajos sobre Costums catalanas y valencianas}

En los años iniciales de su carrera BG dedicó dos estudios a esa área, uno a los

75 «La difusión del Fuero de Jaca en el Camino de Santiago», El Fuero de Jaca. Estudios, Zaragoza, 2004, pp. 111-160. 


\section{Furs de Valencia ${ }^{76}$ y otro a las Costumbres de Lérida, Horta y Miravet. ${ }^{77}$}

$\left.1^{\circ}\right)$ Estado de la investigación

- cuestiones que el estudio de las Costumbres de Lérida plantea: a comienzos del siglo XIII Lérida poseía su carta de población recibida cuando la conquista, además de costumbres no escritas; los cónsules encargan a Guillermo Botet la fijación de todo ese derecho, que queda plasmado en las Consuetudines ilerdenses, sin sanción oficial. Diferentes fechaciones en los distintos manuscritos de los siglos XIV y XV. Los textos de los dos lugares a que se extendieron, Horta y Miravet, no coinciden entre sí ni con Lérida en extensión, presentación ni lengua.

- aportaciones bibliográficas sobre el tema: en especial, la edición con aparato crítico, de Pilar Loscertales.

$2^{\circ}$ ) Fuentes de conocimiento

- las Consuetudines ilerdenses y los privilegios concedidos a la ciudad: se conservan varios manuscritos y se sabe de otros perdidos; el primero es el que Pilar Loscertales consideró más completo, publicándolo con las variantes del resto. Además, se conservan unos privilegios de la ciudad, copiados en forma extractada en el inicio de las Costumbres.

- las Consuetudines et Usancias de Horta: fruto del acuerdo de la villa con la Orden del Temple, en 1296.

- las Costums de la Batllía de Miravet: concedidas por el castellano hospitalario de Amposta, en 1319 .

$3^{\circ}$ ) Tabla de concordancias y cotejo textual

- criterio seguido en la elaboración de la tabla de concordancias

— tabla de concordancias

— resultado del cotejo textual: los dos textos de Ordenes siguen el modelo ilerdense, si bien de forma parcial.

- conclusiones: tanto las costumbres de Horta como las de Miravet proceden de un texto común, que podría serlo también a las de Lérida que conocemos o de un texto leridano originario.

$\left.4^{\circ}\right)$ La evolución de las Consuetudines ilerdenses: el texto originario: el de Botet (originario, no conservado), usado para Horta y Miravet. La formación del texto de Horta. La traducción romance del texto ilerdense y la formación de las Costumbres de Miravet. El texto ilerdense en su versión conocida (tras 1319); sus modificaciones respecto al texto originario.

\subsubsection{Trabajos conclusivos}

Transcurridos más de 20 años de dedicación al estudio de los fueros y con un importante acervo de trabajos publicados, Ana Barrero se sintió con fuerzas para elevar sus miras y proceder a redactar trabajos de carácter genérico, teorizando sobre las conclusiones a las que había llegado en sus estudios.

El primero de estos trabajos, dedicado a los derechos de frontera, vio la luz en 1993: ${ }^{78}$

\footnotetext{
${ }^{76}$ «El Derecho romano en los 'Furs' de Valencia de Jaime I», AHDE, XLI, 1971, pp. 639-664. Conclusiones: la fuente romana fundamental es el Corpus, en especial, el Codex, pero también el Digesto; la otra fuente de inspiración romana fue Lo Codi, pero en mucho menor grado que el Corpus; la influencia romana afecta a todo el contenido de los Furs. Tablas comparativas.

${ }^{77}$ «Las Costumbres de Lérida, Horta y Miravet», AHDE, XLIV, 1974, pp. 485-536.

${ }_{78}$ «Los derechos de frontera», Aragón en la Edad Media. Sesiones de trabajo. II Seminario de Historia Medieval, Zaragoza, 1993, pp. 69-80.
} 
— introducción: similitud de soluciones a problemas parecidos, determinados por cuestiones geográficas y socio-económicas, más que por motivos políticos. Ausencia de un estudio conjunto del derecho de frontera.

- del derecho castellano al de la Extremadura: los inicios en la Castilla condal del siglo X. Inseguridad en el contenido de los mismos, debido a la transmisión tardía de los fueros de la época. A partir de Alfonso VI: amplia repoblación, cuyos textos no se han conservado, bien por haberse perdido, bien por haberse transmitido oralmente; uniformidad en el derecho de la zona, basado en igualdad entre vecinos, por infanzonía, libertades personales en los órdenes económico, penal y procesal, alta autonomía concejil y concesión de amplios alfoces, organizados como comunidades de villa y tierra.

- la frontera pirenaica occidental: fracasado en Soria el modelo de repoblación aragonesa, a fuero de Sobrarbe, Alfonso el Batallador vuelve su mirada al derecho de frontera de sus territorios castellanos (fuero de Medinaceli).

- el «derecho de francos» como derecho de frontera: al quedar cegada la expansión sureña del Reino navarro, la frontera se organiza contra Castilla, usándose el fuero de Logroño para ello, lo mismo que acabará haciéndose en el área vizcaína. También en Toledo aparece el derecho de francos, como derecho privilegiado.

- el desarrollo del derecho de la Extremadura: desarrollado sobre las bases puestas tanto por Alfonso VI en Castilla como por Alfonso el Batallador en Aragón, a partir de ahí se mantiene de manera unitaria, si bien evolucionan en el sentido de intentar comprender la totalidad del ordenamiento local.

- las «fronteras» catalanas: hasta el siglo XII, sobre la base del Liber es suficiente la concesión de cartas de población breves (la de Cardona); llegados al Ebro, se conceden nuevas cartas consensuadas con la población, recogiendo un contenido algo más amplio.

- la tardía recuperación de los fueros de frontera en el Reino de Valencia: sobre dos polos, el fuero de los infanzones y el derecho de la Extremadura; anteriormente a la conquista de Valencia se aplica el derecho aragonés, pero, luego de la toma de la ciudad, el rey decide dar un derecho general a ese Reino. En cambio, el derecho de la Extremadura sólo se aplicó en la zona de Castellón, con los fueros de Morella y de Villahermosa del Río.

\section{En años sucesivos editaría tres artículos más sobre cuestiones metodológicas aso- ciadas al estudio y edición de textos forales; una primera en 1995:79}

$\left.1^{\circ}\right)$ Introducción: estudio complicado debido al gran volumen de fuentes conservadas $(5.000$ referencias en 1.546 voces en su Catálogo), así mismo, plantea problemas la determinación de la autenticidad de los fueros y sus relaciones textuales, que dan una imagen de normas arbitrarias e inconexas.

$2^{\circ}$ ) El problema de la autenticidad documental: ausencia de diplomas originales, hasta el reinado de Fernando III; anomalías diplomáticas generalizadas; dificultad de discernir entre documentos apócrifos y textos redactados privadamente a partir de documentos reales originales, muchas veces a instancias del municipio. Esto es especialmente así en los fueros extensos.

$3^{\circ}$ ) Cuestiones derivadas del análisis de las relaciones textuales: esto sucede cuando un lugar adopta el fuero privilegiado de otro distinto; cuando esto ocurre con cierta profusión se habla

\footnotetext{
${ }^{79}$ «El proceso de formación de los fueros municipales (Cuestiones metodológicas)», Espacio y fueros en Castilla-La Mancha (siglos XI-XV). Una perspectiva metodológica, Madrid, 1995, pp. 59-88. El mismo trabajo había sido editado seis años antes, con ligeras variaciones, bajo el título «El derecho local en la Edad Media y su formulación por los reyes castellanos», Anales de la Universidad de Chile. Estudios en honor de Alamiro de Ávila Martel, 1989, $5^{\mathrm{a}}$ serie, nº 20, pp. 105-130.
} 
de familias de fueros. En ocasiones, el fuero de un lugar tomado de otro no coincide con el texto conservado en el lugar de origen

$\left.4^{\circ}\right)$ Resultados de la crítica diplomática y textual: el proceso de formación del derecho local y sus diferentes fases de redacción

$\left.5^{\circ}\right)$ La evolución del derecho local en el Reino castellano-leonés:

— su proceso de formación y fijación inicial: los primeros tiempos, la política foral de Alfonso VI y la continuidad de su obra.

- su afianzamiento y desarrollo: la intensificación del proceso redaccional; la política real de unificación jurídica del Reino a través de los derechos locales; y la revitación y fijación definitiva de los derechos locales.

- las consecuencias del Ordenamiento de Alcalá (prueba de uso en el orden de prelación).

\section{En el segundo de esos estudios, presentado al Congreso sobre el fuero de Santan- der, vuelve a tratar la misma problemática, de modo algo más extenso. ${ }^{80}$}

$\left.1^{\circ}\right)$ Introducción: ¿es suficiente el estudio de los fueros o hay que seguir con ello? ¿deben renovarse los planteamientos metodológicos?

$2^{\circ}$ ) El estado actual de la investigación: especial atención a la edición de textos; enorme dispersión de las publicaciones; escaso rigor científico en ocasiones. Falta de estudios críticos introductorios. No abundan los estudios sobre los fueros al margen de su edición. Ausencia de síntesis de carácter general. Por ello, es preciso seguir con el estudio del derecho local.

$3^{\circ}$ ) Problemas que plantean el estudio de los fueros: la pluralidad de textos diferentes. Problemas formales: falta de cláusulas diplomáticas habituales, anacronismos, acarreo de materiales diversos dentro de un texto. Diversidad en la categoría de los fueros breves, verdadero cajón de sastre: cartas de población, contratos agrarios, privilegios concretos.

Falta de actuación uniforme en las cancillerías regias antes del Emperador, de modo que hasta principios del siglo XII todos los fueros presenten anomalías. En esos momentos, a falta de criterios diplomáticos, hay que considerar los anacronismos institucionales o personales, siempre dentro del ámbito ancho de la probabilidad.

A partir de Alfonso VII el panorama varía: se conceden los fueros de un lugar a otro, sacando el concejo sus copias propias y atribuyéndoselas a un monarca. Conviven, pues, normas amparadas por privilegios reales y recopilación de fueros, confirmados de modo oral o genéricamente por los soberanos. Existencia de familias de fueros, que incluyen textos reelaborados en distintos lugares, dando redacciones distintas.

Plantea la hipótesis de la formación progresiva de los textos a partir de los primeros privilegios concedidos por reyes y señores.

$4^{\circ}$ ) Las distintas fases de redacción del derecho local: si se considera que los fueros fueron creados progresivamente y no son el resultado de una decisión unitaria inicial se pueden resolver los problemas textuales. Esto no quiere decir que la autoridad real esté ajena totalmente al proceso, pues estaba en juego el prestigio de la monarquía. Si no han estado presentes los reyes en el momento inicial, frecuentemente intervienen en confirmaciones de las recopilaciones. Una primera fase en ese proceso alcanza los reinados de Alfonso VI y Alfonso VII; una segunda durante el siglo XIII, operando sobre la Extremadura y el Reino de Toledo. Dos hechos: la promesa

\footnotetext{
80 «Observaciones al estudio de los Fueros», Fuero de Santander y su época. Actas del Congreso conmemorativo de su VIII centenario, Santander, 1997, pp. 189-206. Temas tratados en el debate posterior: con MD sobre los fueros de época condal; sobre las interpolaciones simples y las falsificaciones; sobre la distinción fuero breve/fuero extenso. Con García de Cortázar sobre el Catálogo de Fueros. Con Iglesia Ferreirós sobre la confirmación oral de los fueros por el Rey.
} 
de Alfonso VIII de confirmar los fueros municipales tras la batalla de las Navas, truncada por su fallecimiento, pero cumplida por Fernando III (textos de mayor extensión y riqueza de contenido que los de la época anterior), rey que continuará una política de uniformización allí donde podía, en la frontera. Tras el fracaso de Alfonso X hay una vuelta a los textos anteriores, que resultan revitalizados. Tras el Ordenamiento de Alcalá la prueba de uso de los fueros supuso una importante cortapisa a su utilización.

Aún más extenso es el último de sus estudios conclusivos, de 2001, que, de no ser porque $\mathrm{BG}$ ha seguido produciendo trabajos posteriormente, podría considerarse su testamento en lo relativo al mundo foral. ${ }^{81}$

a) planteamiento: variedad enorme de fuentes desde el siglo $\mathrm{X}$ a fines de la Edad Media; bibliografía y ediciones abundantes, enfocadas desde un paradigma racionalista, que hacía necesario un tratamiento desde la crítica diplomática y textual, debido a los frecuentes anacronismos, incoherencias y contradicciones.

b) los problemas de autenticidad documental: se ha distinguido entre cartas (fueros breves) y libros (fueros extensos); destacan la escasez de diplomas originales y la generalidad de las anomalías en la cartas de fueros. ¿Existieron alguna vez esos originales? se pregunta BG. Respecto a las anomalías, defiende la utilidad de las críticas diplomática e histórica. La reacción a estos hallazgos por los especialistas es diversa, llegando algunos a sentenciar el carácter apócrifo del documento interpolado o con carencias diplomáticas. En unos casos se redacta teniendo presente el privilegio regio, en otros se suple una concesión regia de carácter oral, luego no sustanciada por escrito por el monarca; en otros, el rey acepta la validez presentado a su confirmación. La falta de autenticidad diplomática, pues, no condiciona su autenticidad histórica. Si bien, existen documentos claramente falsos, a pesar de presentarse con aspecto de auténticos. El tiempo de redacción de la compilación foral puede ser largo, encontrándose, entonces, diversos estratos que son desvelados por el estudio interno del documento. Esto es particularmente cierto en lo relativo a los fueros extensos, por regla general, ajenos a la actividad cancilleresca.

c) alcance y significado de las relaciones textuales: deben estudiarse cuando un texto de un lugar se ha concedido a otro, parcialmente o en su totalidad. Esto da lugar a las familias de fueros. En la concesión se puede reproducir o no el texto que se extiende. Cuando se reproduce, el texto reproducido no corresponde frecuentemente con su fuente conservada; en otras ocasiones, aunque no se establezca una relación con un texto previo, el contenido delata esa dependencia. En la Extremadura el arraigo de un ordenamiento tradicional favorece la uniformidad relativa entre los distintos textos, lo que ocurre especialmente con el prestigioso FC.

d) el proceso de formación del derecho local y sus diferentes fases de redacción: conclusiones, diplomas forales no suelen proceder de las cancillerías, sino de medios locales favorecidos por concesiones reales o señoriales; no representan una redacción unitaria, sino que compilan normas de distinta procedencia; hasta alcanzar su redacción definitiva se producían varios intentos sucesivos; al fijarse por escrito el texto permite su conocimiento y difusión. Así pues, según BG, hay que abandonar la visión positivista y entender que los fueros son el resultado de una voluntad comunitaria de regular su convivencia. Para favorecer su legitimidad se atribuyen a la autoridad que inicialmente concedió su carta de población. Este esfuerzo compilador se inicia en el primer tercio del siglo XII en las zonas de repoblación. La recepción del Derecho común no fue ajena a esta marea.

${ }^{81}$ «El proceso de formación del derecho local medieval a través de sus textos: los fueros castellano-leoneses», I Semana de Estudios Medievales, Nájera, 2001, pp. 89-129. 
e) la evolución del derecho local en el Reino castellano-leonés: es en este Reino donde más claramente se aprecia esta realidad; hitos diferenciales, la victoria de las Navas de Tolosa y el Ordenamiento de Alcalá.

1) génesis y su fijación inicial:

- los primeros tiempos: en la época condal aparecen los primeros fueros castellanos, luego decantados en el Fuero de Sepúlveda; distinta situación la del Reino de León, pues los inmigrantes mozárabes favorecen la aplicación del Liber y sólo Alfonso V conde Fuero a León. Fernando I sólo concederá algunos fueros a ambos reinos, así como al territorio portucalense.

— la política foral de Alfonso VI: gran esfuerzo repoblador y foral. Caracteres, amplitud cuantitativa de concesiones forales; escasas en sus inicios, se extienden por todo el resto del reinado; concesiones centradas en la frontera sur y en la retaguardia, en el Camino de Santiago. Aunque no todos los textos que se le atribuyen proceden de su cancillería, se aprecia una clara voluntad regia en fomentar el aforamiento.

- la continuidad de su obra: es continuada por Alfonso VII y sus sucesores, Fernando II y Alfonso IX en León, y Alfonso VIII en Castilla. Sus confirmaciones de fueros incentivan que las comunidades locales procedan a redactar sus ordenamientos para presentarlos en la Corte. Estos monarcas, además, se ocuparon de las nuevas pueblas, usando los fueros de la época de Alfonso VI, como ocurrió con los fueros de Sahagún o Benavente. El de Logroño serviría para aforar a una amplia zona.

2) afianzamiento y desarrollo:

— la intensificación del proceso redaccional: en el primer tercio del siglo XIII, a tenor de la promesa de Alfonso VIII de confirmar, tras las Navas, los fueros de la Extremadura, los concejos se ponen manos a la obra para redactar amplias recopilaciones; en León, Zamora, Alba de Tormes, Salamanca, Ledesma o Ciudad Rodrigo. En Castilla, Guadalajara, Madrid, Molina de Aragón, Alcalá de Henares, Brihuega, Fuentes de Alcarria o Uclés. Y, especialmente, Cuenca.

- la política de unificación jurídica del Reino: Fernando III decide acometer la unificación del ordenamiento, realizando una labor preparatoria; realiza la promesa de Alfonso VIII se confirmar los fueros extremaduranos, ordena pesquisas para aclarar situaciones de conflicto, pero, sobre todo, busca la unificación en las tierras nuevamente conquistadas (en la zona cantábrica se usa el fuero de Benavente y el de San Sebastián), usando el FC en las áreas norteñas de Jaén y Murcia y el Liber en el resto de Andalucía y Murcia.

Con Alfonso X la política foral es sustituida por la legislativa. Se extiende el FR hasta la crisis de 1272 y su secuela, las Cortes de Zamora de 1274.

- la revitalización y fijación definitiva de los derechos locales: tras la vuelta al derecho tradicional, algunos concejos proceden a realizar sus recopilaciones locales o a revisiones de las mismas, bien para uso interno, bien para ser utilizadas por otros concejos diferentes. Paulatinamente se aprecia la insuficiencia de esos textos, estableciéndose la prueba de uso en el orden de prelación de fuentes de Alcalá.

- las consecuencias del Ordenamiento de Alcalá: se limita su uso, pero se garantiza su supervivencia hasta fines del Antiguo Régimen. Para probar el uso los concejos profundizan en la reelaboración de sus textos forales. Valor político de los mismos, invocado por los Reyes Católicos en la repoblación del Reino de Granada y en las Islas Canarias.

Aprovechando su ganada aureola de investigadora experta en textos medievales, BG sería invitada en dos ocasiones a realizar sendas exposiciones globales, una sobre las fuentes histórico-jurídicas hispánicas, en la Enciclopedia dirigida por su primer maestro, ${ }^{82}$ y otra sobre el derecho medieval. ${ }^{83}$

\footnotetext{
${ }^{82}$ «Las fuentes del Derecho Histórico Español», Enciclopedia de Historia de España dirigida por Miguel Artola. VII. Fuentes. Indice, Madrid, 1993, pp. 229-335.
} 
$\left.1^{\circ}\right)$ Planteamiento

$\left.2^{\circ}\right)$ La «superacion del medievalismo» ¿un eufemismo historiográfico?: acuñado por Tomás y Valiente; situación de la historiografía a la altura de 1974, según GG:

— polarización en la Alta Edad Media, cuyo derecho sería emanación del germanismo,

- apertura progresiva a la época moderna,

- crisis del germanismo español y

— necesidad de abordar la historiografía desde el Derecho Común y no sólo desde las fuentes nacionales.

$\left.3^{\circ}\right)$ Constitución e historiografía: renovación por la Constitución de 1978.

$4^{\circ}$ ) Tendencias temáticas y metodológicas de la Historia del Derecho: la España autonómica ha propiciado la aparición de nuevas universidades, con preocupaciones regionales y locales antes mal atendidas, y con el alumbramiento de nuevas revistas especializadas. Proliferación de reuniones científicas. Todo ello ha incidido en la renovación metodológica.

$5^{\circ}$ ) La historiografía jurídica sobre la Edad Media:

— edición y estudio de fuentes del Derecho: textos normativos y jurisprudenciales.

- el estudio de las instituciones: modernas de carácter público. El ámbito penal desde la BEM, Hermandades, etc. Dos perspectivas: interés por las instituciones públicas e importancia de los particularismos. El poder real, en Castilla, señorial, municipal; derecho mercantil, privado.

\section{Conclusiones}

Llegados a este punto, es el momento de preguntarse sobre si se ha cumplimentado el programa diseñado por García-Gallo en su artículo de 1956. Desde luego, no cabe la menor duda de que el proyecto de culminar la obra iniciada a mediados del siglo XIX por Muñoz y Romero se coronó con éxito en 1989, con los Textos de Barrero y Alonso, si bien, como cualquier investigador sabe, dar por cerrado definitivamente un tema es ilusorio, pues siempre aparecerán nuevos elementos que incorporar al acervo documental.

En cuanto al estudio sistemático de los fueros y sus familias desde un punto de vista histórico-crítico, hay que reconocer que, gracias, especialmente, a los trabajos de García-Gallo y de Barrero García, se ha avanzado en gran medida, siempre teniendo en cuenta el alto grado de incertidumbre en que nos movemos cuando ascendemos al campo de las hipótesis no respaldadas por textos conservados.

Finalmente, cabe preguntarse si los discípulos de GG han seguido las indicaciones de su maestro en el ámbito de los fueros municipales. No resulta fácil contestar a esta pregunta: de hecho, la preocupación de GG por los fueros ha dado como resultado que prácticamente todos sus discípulos hayan manejado los textos forales para sus

\footnotetext{
${ }^{83}$ «El derecho medieval y la historiografía jurídica (1968-1998)», La Historia Medieval en España: un balance historiográfico (1968-1998), Pamplona, 1999, pp. 747-778.

El otro polo de interés de Ana Barrero es el mundo indiano; a caballo entre los dos mundos cabe situar su contribución al Congreso de Derecho Indiano de 2000 ( «De los fueros municipales a las ordenanzas de los cabildos indianos. Notas para su estudio», VIII Congreso Internacional de Historia del Derecho Indiano, 2000, I, pp. 29-42 [publicación digital]). Lamentablemente, no he podido consultar esta aportación.
} 
estudios, algo particularmente apreciable en los trabajos de Martínez Gijón y sus discípulos, en los de Mari Luz Alonso o en el de Sánchez-Arcilla, ${ }^{84}$ sea para tratar temas institucionales o, en especial, cuestiones de derecho privado.

Ahora bien, ninguno de éstos ahora citados se han ocupado de la crítica textual, histórica o diplomática, salvo el propio GG y BG, y parciamente MD; éste, en cierto modo, ha seguido su propio camino, intentando rescatar de los archivos los textos forales de amplias zonas de la Castilla nuclear y sus aledaños, así como estudiando el Fuero Real y sus relaciones con el de Soria.

De hecho, sólo BG ha seguido fielmente el método analítico propuesto por GG, en una línea de continuidad que ha intentado tocar todos los palos posibles. Sin embargo, como ha quedado bien claro, a pesar de todos los encomiables esfuerzos realizados por unos y otros - y por otros autores fuera de dicha escuela - aún queda por establecer el stemma más complejo: el de la familia del Fuero de Cuenca. Con los medios informáticos con los que hoy contamos no debería ser una misión imposible durante mucho tiempo más. Puede decirse, a este propósito, que estamos en tiempo de descuento, pues han pasado 15 años sobre el mínimo de 25 necesarios, diagnosticado por MG en 1971.

\footnotetext{
${ }^{84}$ «El derecho especial de los Fueros del Reino de León (1017-1229)», El Reino de León en la Alta Edad Media. II. Ordenamiento jurídico del Reino, León, 1992, pp. 185-380.
} 